\title{
Education and training for librarianship and information work: Annual bibliography, 1991
}

\author{
Alan J. Clark \\ Librarian, Information and Library Studies Library, University of Wales Aberystwyth, Llanbadarn \\ Fawr, Aberystwyth, Dyfed SY23 3AS, United Kingdom
}

The 1991 bibliography follows its established pattern, covering items published worldwide during the previous year.

Subject access is provided by the contents list and classified arrangement and through a subject index which includes entries for countries and regions. The name index includes entries for authors and name subject entries for individual organisations and programs. 


\section{CONTENTS}

BIBLIOGRAPHIES 001-002

RESEARCH 003-010

GENERAL ITEMS - UNIVERSAL 011-044

GENERAL ITEMS - INDIVIDUAL REGIONS AND COUNTRIES 045-165

LIBRARY AND INFORMATION SCIENCE SCHOOLS AND DEPARTMENTS

General 166-168

Accreditation 169-171

Curriculum development 172-174

Courses/study $175-191$

Professional

First qualification $175-181$

Advanced courses 182-185

Paraprofessional 186-191

Modes of study 192-205

Part time 192

Distance education 193-205

Teaching methods 206-216

Specialised education 217-244

Academic librarianship 217-219

Acquisitions 220-222

Agricultural librarianship 223-224

Art librarianship 225

Children's librarianship 226-228

Conservation and preservation librarianship 229-230

Law librarianship 231-233

Media librarianship 234

Music librarianship 235-240

Public librarianship 241

School librarianship 242

Serials librarianship 243-244

Teaching individual subjects 245-262

Artificial intelligence 245

Bibliographic instruction 246

Bibliography 247-250

Bibliotherapy 251

Content analysis 252

Expert systems 253

Information design 254

Information retrieval 255-256

Information technology 257

Marketing 258

Reference and information service $259-260$ 
Research methods 261

Subject indexing 262

Practical work experience 263-269

Teaching staff/Faculty $270-284$

Students 285-294

Individual schools 295-320

PROFESSIONAL QUALIFICATIONS 321-325

CAREER DEVELOPMENT 326-343

CONTINUING EDUCATION 344-375

TRAINING 376-437

General 376-387

Specialised 388-437

ROLE OF ASSOCIATIONS AND SOCIETIES IN LIBRARY EDUCATION 438-453

EDUCATION AND TRAINING FOR RELATED OCCUPATIONS 454-462

EMPLOYMENT MARKETPLACE 463-482

NAME INDEX

SUBJECT INDEX

LIST OF PERIODICAL TITLE ABBREVIATIONS 


\section{ANNUAL BIBLIOGRAPHY, 1991}

\section{BIBLIOGRAPHIES}

001. CLARK, Alan J. Education and training for librarianship and information work: annual bibliography, 1990. Education for Information 9(3) 1991 167-224.

002. FONTAINE, France and BERNHARD, Paulette. Bibliography from Guidelines for writing learning objectives in librarianship, information science and archives administration. Information: Reports and Bibliographies 20(1) 1991 18-22.

\section{RESEARCH}

003. ALI, S. Nazrim and TIKKU, Upinder Kumar. Postdoctoral research in library and information science: is there a need? J.Educ.Lib.\& Inf.Sci. 31(4) 1991 362-364.

004. CALVERT, Philip J. Library research for the 1990s. New Zealand Libraries 46(12) 1991 8-10.

005. CARMICHAEL Jr., James V. Ahistoricity and the library profession: perceptions of bibliographical researchers in LIS concerning research problems, practices and barriers. J.Educ.Lib.\& Inf. Sci. 31(4) 1991 329-355.

006. CHU, Clara M. and WOLFRAM, Dietmar. A survey of the growth of Canadian research in information science. Can.J.Inf.Sci. 16(1) 1991 12-28.

007. DELLA CAVA, Olha. Resources for scholars: four library and information science collections. Part 2 Columbia University and American Library Association. Library Quarterly 61(1) 1991 41-60.

008. HARRIS, Colin. Research policy in librarianship and information science: papers presented to a conference of the Library and Information Research Group and the Public Libraries Research Group Salford, 1990. London: Taylor Graham, 1991. ISBN 094756849 2. (British Library Research and Development Report; No. 6010).

009. McCLURE, Charles R. \& HERNON, P. eds. Library and information science research: perspectives and strategies for improvement. Norwood N.J.: Ablex, 1991. ISBN 0893911731. 
010. MEADOWS, Jack. National library and information research planning and policy with special reference to the United Kingdom. Alexandria 3(3) 1991 149-160.

\section{GENERAL ITEMS - UNIVERSAL}

011. Alliances toward the improvement of information science education worldwide. Proceedings of a session at ASIS 53rd Annual Meeting Toronto 1990. J.Educ.Lib.\& Inf.Sci 32(1/2) 1991 3-126.

012. AMAT, Nuria. El documentalista: un cientifico de cientificos. Rev.Esp.Doc. Cient. 14(2) 1991 179-186.

013. AVISON, D.E. and FITZGERALD, G. Information systems practice, education and research. J.Inf.Sys. 1(1) 1991 5-17.

014. BERRY, J.N. Will library education survive? Library Journal 116(4) 1991 55-56.

015. Bibliotekarieutbildningen i framtidengenomgripande forslag till fornyelse. Nordinfo Nytt 14(3) 199146.

016. BIGGS, Mary. The scholarly vocation and library science. In Godden, I.P. ed. Advances in librarianship V.15 Academic Press, 1991. ISBN 012 0246155. pp 29-75

017. CRONIN, Blaise. Information professionals in industrial countries. Rev.Esp. Doc.Cient. 14(1) 1991 47-56.

018. DE BRUIN, H. Inligtingbestur in die organisasie: 'n bestuuraamwerk vir identifisering van uitdagings aan bibliotheek- en inligtingskundiges. S.Afr.J.Library \& Inf.Sci. 59(2) 1991 105-111.

019. EVANS, Jennifer. Educating for change: grasping the vision. Educ.Lib.Aust. 8(2) 1991 3-9.

020. FORGIONNE, Guisseppi A. The college of information science: a mechanism to consolidate information science education. Education for Information 9(4) 1991 285-304.

021. FORGIONNE, G.A. Providing complete and integrated information science education. Inf.Proc.\& Man. 27(5) 1991 575-590.

022. GROSSER, Kerry. Human aspects of organisational information processing: implications for educating information professionals. Educ.Lib.Aust. 8(2) 1991 $18-21$.

023. HERRING, J.E. Information Management - the convergence of professions. Int.J.Inf.Man. 11(2) 1991 144-155. 
024. LANCASTER, F. Wilfrid. What has Unesco achieved in education and training for the information professions? J.Educ.Lib.\& Inf.Sci. 32(1/2) 1991 69-76.

025. McKNIGHT, S. Amalgamations and the implications for library education. Educ.Lib.Aust. 8(2) 1991 22-27.

026. MEADOWS, Jack. Information science. Brises No.16 1991 9-13.

027. MENOU, Michel J. Sharing imagination. [Editorial]. J.Educ.Lib.\& Inf.Sci. 32(1/2) 1991 3-7.

028. NICHOLSON, Fay. Multiskilling: implications for library and information science education. Educ.Lib.Aust. 8(2) 1991 35-40.

029. NOSEK, John T. and YAVERBAUM, Gayle. Overcoming obstacles to university and industry synergy in information system education: lessons from action research. Education for Information 9(1) 1991 3-19.

030. Report on the Annual Meeting of the IFLA Section on Library Education and Training Stockholm August 18-22, 1990. J.Educ.Lib.\& Inf.Sci. 31(3) 1991 261-263.

031. ROCHESTER, Maxine. The impact of political, economic and social trends on education for librarianship: report on the 57th IFLA Conference, Moscow 18-24 August 1991. Educ.Lib.Aust. 8(1/3) 1991 29-34.

032. RUOHONEN M. Information Management Education in human resource strategy. Int.J.Inf.Man. 11(2) 1991 126-143.

033. SCHLESSINGER, Bernard S., SCHLESSINGER, June H. and SCHLESSINGER KARP, Rashelle. Information science/library science education programs in the 1990s: a not-so-modest proposal. Lib.Admin.\& Man. 5(1) 1991 16-19.

034. STOKES, S.L. The new IS manager for the 1990s. J.Inf.Sys.Man. 8(1) 1991 44-50.

035. TEES, Miriam. Harmonization of education and training for information professionals. IFLA Journal 17(3) 1991 232-234.

036. TEES, M. IFLA Section on Education and Training. [In Russian]. Bib.i.Bib.Rub. 1991129 20-31.

037. TEES, Miriam. Special issue on education and training. [Editorial]. IFLA Journal 17(3) 1991 227-228.

038. Training for the information professional. Library Monitor No.28 1991 6-10.

039. TRASK, Margaret. Relevance for reality: whose responsibility? Educ.Lib.Aust. 8(2) 1991 41-59. 
040. VAN BRAKEL, P.A. Training information specialists in an integrated information environment: a situation analysis. In D.E. Raitt ed. Online Information '91. Oxford: Learned Information, 1991. ISBN 090493379 2. pp.183-194

041. VIRGO, Philip. The IT Education and training debate: 1981-91. Inf.Tech. Publ.Pol. 9(2) 1991 107-108.

042. WEBB, Sylvia P. Human resources management for the year 2000 - Recruitment. Outlook on Research Libraries January 1991 1-3.

043. WEDGEWORTH, Robert. Some thoughts on the perils of library education: real and perceived. Wilson Library Bulletin 65(5) 1991 46-48.

044. WORMELL, Irene. Az informacios menedzserek szerepe a gazdasagi szervezetekben: oktatasi es kepzesi szempotok. Tud.Mus.Taj. 38(5/6) 1991 209-215.

\section{GENERAL ITEMS - INDIVIDUAL REGIONS AND COUNTRIES}

Africa

045. ADIMORAH, E.N.O. Training for rural library and community information centre management. Education for Information 9(1) 1991 55-59.

046. AIYEPEKU, W. Olabode. The challenge of implementing an African programme in information science: TRARECON. J.Inf.Sci. 17(5) 1991 315-320.

Asian Pacific

047. ROCHESTER, Maxine K. Emergence of the Asian Pacific area and its impact on education and training of librarians. In Proceedings 57th IFLA General Conference Moscow 18-24 August 1991. (Paper 71-ET-1-E).

Australia

048. KENCHINGTON, Carol. The attitudes of the library profession to training and development issues and the role of the library and information schools in training provision. Educ.Lib.Aust. 8(2) 1991 78-81.

049. LAYZELL-WARD, Patricia. The cultural aspects of colonialism: a case study of the relevance of the imported curriculum for library and information science education to the needs of Western Australian society. In Proceedings 57th IFLA General Conference Moscow 18-24 August 1991. (Paper 72-ET-2-E). 


\section{Bangladesh}

050. AHMAD, Nasiruddin. Problems and prospects of library education in Bangladesh. Her.Lib.Sci. 30(1-2) 1991 46-50.

\section{Belgium}

051. DE SMET, Egbert. De Vlaamse bibliotheekopleidingen: een bloemistenvisie. Bibliotheek en Archiefgids. 67(3) 1991 307-309.

\section{Canada}

052. APOSTLE, Richard and RAYMOND, Boris. Library and information work in Canada: further analysis of an emerging labour market. Can.J.Inf.Sci. 16(2) 1991 40-51.

\section{China}

053. LEE, Peijun. Education for information science in China. Education for information 9(3) 1991 249-251.

\section{Denmark}

O54. CLAUSEN, Helge. The future information professional: old wine in new bottles. Part 2. Libri 41(1) 1991 22-36.

055. NYENG, Per. Skal professionen udvikles ma autonomien fastholdes. Bibliotek 70 No 151991 416-421.

\section{Europe}

056. SMITH, Dag. Common standards for education and training in Europe. Serials 4(1) 1991 51-53.

057. VODOSEK, Peter. Ausbildung in Europaischen Rahmen: EUCLID in Stuttgart gegrundet. Bibliotheksdienst 25(11) 1991 1733-1735.

058. VODOSEK, Peter. Dritte Sitzung der BDB-Arbeitsgruppe "Ausbildung im Europaischen Rahmen. Bibliotheksdienst 25(6) 1991 837-841.

059. WOOD, Kate. Reconnaissance mutuelle des diplomes dans la Communaute Europeene. Bull.Bib.France 36(1) 1991 58-63.

060. WOOD, Kate. Reconnaissance mutuelle des diplomes professionnels dans la Communaute Europeene. Bull.Inf.ABF No.150 1991 71-77. 


\section{Finland}

061. LAAKSOVIRTA, Tuula H. and VILJAKAINEN-TIITTANEN, Merja. Education and qualification now and in 1992. Scand.Pub.Lib.Q. 24(4) 1991 9-11.

062. LAAKSOVIRTA, Tuula H. Muuttuuka patevyden maarittely? Kirjastolehti No.2 1991 46-47.

063. POTERI, Eija. Kirjastonhoitajakoulutuksen pioneerikavsi Suomessa 19201945. Kir.ja.Inf. 10(1) 1991 3-16.

064. VILJAKAINEN-TIITTANEN, Merja. Koulutuksen uudet hammentavat kuviot: Ketjusilmukasta kirjoneuleeseen? Kirjastolehti No.9 1991 272-273.

\section{France}

065. BERTRAND, Anne-Marie. Specialisation generaliste. Bull.Inf.ABF No.150 1991 45-46.

066. BETHERY, Annie. Formation moyenne: Seminaire d'Auxerre. Bull.Inf.ABF No.153 1991 53, 55-56.

067. BONNARDEL, Anne-Francoise. La formation elementaire "ABF". Une longue et patiente pratique. Bull.Inf.ABF No.150 1991 11-13.

068. BOSC, Catherine. Analyse de la situation en Franche-Comte 1970-1990. Bull.Inf.ABF No.150 1991 17-19.

069. BOULBET, Genevieve. Faut-il former les benevoles du reseau des B.C.P? Bull.Inf.ABF No.150 1991 23-25.

070. BRETHES, Jean-Piere. Magasiniers et employes de bibliotheques: pour une formation. Bull.Inf.ABF No.152 1991 11-12.

071. DEMADRE, Anne-Marie. La formation professionnelle en Auvergne. Bull.Inf.ABF No.150 1991 26-27.

072. Dossier: Theories et pratiques de la formation professionnelle: une brassee d'experiences et de reflexions. Bull.Inf.ABF No.150 1991 6-77.

073. GASC, Michele. Quelques pistes pour demain et apres-demain. Bull.Inf.ABF No.150 1991 69-70.

074. GINTRAND, Phillippe. Les metiers de la librarie. Bull.Inf.ABF No.152 1991 37-38.

075. GIRARD, Christine. La Commission Pedagogique nationale des Centres regionaux de formation aux carrieres des bibliotheques, du livre et de la documentation. Bull.Inf.ABF No.150 1991 37, 39. 
076. GLEYZE, Alain and RENOULT, Daniel. Formation professionnelle des bibliothecaires et enseignment superieur: quelques reflexions sur les evolutions recentes. Bull.Inf.ABF No.150 1991 63-66.

077. GOASGUEN, Jean. Concours de bibliothecaire - adjoint et de bibliothecaire - adjoint principal. Bull.Inf.ABF No.150 1991 40-42.

078. GUYOT, Brigitte. L'interprofessionnalisme. Bull.Inf.ABF. No.152 1991 34-35.

079. HECQUARD, Francoise. Evolution en cours (Quelques elements d'un projet de memoire de DSB/DESS ENSB 1990/1991). Bull.Inf.ABF No.150 1991 14-16.

080. HECQUARD, Francoise. La formation elementaire: Seminaire de Nevers Juin 1991. Bull.Inf.ABF No.152 1991 9-11.

081. HECQUARD, Francoise. Reflexion pedagogique de la Commission Formation Elementaire de l'ABF. Bull.Inf.ABF No.152 1991 12-13.

082. HERMAN, Nadine. La Centre National de la fonction publique territoriale et la formation. Bull.Inf.ABF No.150 1991 68-69.

083. KERIGUY, Jacques. Les defis de L'Ecole Nationale Superieure des Bibliothecaires. Bull.Inf.ABF No.150 1991 57-62.

O84. LAMBLIN, Pierre-Jacques. C.A.F.B. Notes et reflexions pour un bilan. Bull.Inf.ABF No.150 1991 29-30.

085. MORIS, Joel. L'inexorable evolution du metier. Bull.Inf.ABF No.150 1991 46-50.

086. PAULIDES, Christophe. La formation au patrimoine des bibliotheques: le role du Ministere de l'Education Nationale. Bull.Inf.ABF No.152 199139.

087. PIQUEMAL, Marcel. Fonction publique et formation professionnelle. Bull.Inf.ABF. No.152 1991 32-33.

088. RIOUX, Jean-Pierre. L'evolution des politiques culturelles et les metiers de la bibliotheque. Bull.Inf.ABF No.152, 1991 46-47, 49-51.

089. SABY, Frederic. Le bureau de la formation de la Direction du livre et de la lecture: reflexion sur une courte experience. Bull.Inf.ABF No.150 1991 43-44.

090. SABY, Frederic. La formation superieure. Seminaire du Creusot Juin 1991. Bull.Inf.ABF No.152 1991 16-17.

091. TABET, Jean. Chronique d'une mort programmee. Bull.Inf.ABF No.150 1991 $51-56$.

092. VINGTDEUX, Nelly. Les pratiques de la B.C.P de l'Ardeche. Bull.Inf.ABF No.150 1991 19-22. 


\section{Germany}

093. FUNK, Robert, HARTMANN, Christian and JANSCH, Wolfgang. Diskussion: Gesamtberliner Ausbildung im Bibliothekswesen, Information und Dokumentation. Informatik 38(3) 1991 103-105.

094. JANSCH, Wolfgang. Anforderungen an die Ausbildung in den neuen Bundeslandern. Informatik 38(6) 1991 209-214.

095. MAUGH, Bertold. Die bibliothekarische Ausbildung in Deutschland: Problems Entwicklungen, Tendenzen. Buch u.Bib. 43(5) 1991 426-428, 430-434.

096. OLLERMAN, Elke. Die Ausbildung fur das offentliche und wissenschaftliche Bibliothekswesen der Deutschen Demokratischen Republik 1949-1990. Hannover: Fachhochschule Dipl-Arb, 1991.

097. RUSCH-FEJA, Diann. Reciprocity of qualifications in practice: equivalency issues affecting the librarian and documentation professions in Germany after reunification in 1990. Educ.Lib.Aust. $81 / 31991$ 20-28 and In Proceedings 57th IFLA General Conference Moscow 1991 (Paper 152-ET-4.E).

098. Was wird aus unseren Hoch-und Fachschulabschlussen. Informatik 38(3) 1991 107.

099. WERNER, Rosemarie. Erneuerung der Bibliothekar- und Dokumentarausbildung in Berlin: Konzeptionelle Vorarbeiten der ehemaligen "Fachschule fur wissenschaftliche Information und wissenschaftliche Bibliothekswesen. Bibliotheksdienst 25(5) 1991 671-688.

\section{Ghana}

100. ALEMNA, A.A. Characteristics and careers of past post-graduate diploma students of the Department of Library and Archival Studies, University of Ghana, Legon 1981/82-1987/88. Education for Information 9(2) 1991 121-128 and African Journal of Library, Archives and Informaton Science 1(1) 1991 45-50.

101. ALEMNA, A. Anaba. Education and training for library management in Ghana. Library Management 12(5) 1991 13-17.

102. ALEMNA, A.A. Education for librarianship and education in Ghana. J.Educ.Lib.\& Inf.Sci. 32 (3/4) 1991 242-246.

103. BOYE, Mary I.S. Education for library and information work in Ghana: challenges of the new decade. Int.Lib.Rev. 23(3) 1991 175-181. 
Iceland

104. CLYDE, Laurel A. Under the Northern Lights: Teaching library and information science in Iceland. Educ.Lib.Aust. 8(1/3) 1991 35-47.

India

105. ASUNDI, A.Y. Specialisation in library and information science education. Her.Lib.Sci. 30(3-4) 1991 249-251.

\section{Indonesia}

106. PRINGGOADISURJO, J. Issues and challenges in library development. Information Development 7(2) 1991 78-80.

Italy

107. BRAMBILLA, Romeo. Scuola e cultura della documentazione. Biblioteche Oggi 9(5) 1991 634-636.

108. BRAMBILLA, Romeo. Utenza studentesca: vecchie strutture, nuovi bisogni. Biblioteche Oggi 9(1) 1991 107-109.

109. HOLM, Liv A. Hoyere bibliotekarutdannelse Italia: BRODD med i planleygingen. Synopsis 22(4) 1991 227-228.

110. MARZANO, Gilberto and DANIN, Antonio. Pratica documentale e nuovi scenari professionali. Biblioteche Oggi 9(2) 1991 159-166.

111. SOLIMINE, Giovanni. Universita e formazione. Biblioteche Oggi 9(1) 1991 105-106.

Japan

112. MIURA, Itsuo et al. Knowledge bases for academic librarians and library education I: a survey of the academic librarian's view of library education. Ann.Jap. Soc.Lib.Sci. 37(2) 1991 49-63 and Part II 37(3) 1991 103-116.

Kenya

113. GIKENYE, M. Wakari. The library school is here now, what are the implications? COMLA Newsletter No.72 1991 2-3.

114. ROSENBERG, Diana. Recruitment into the information professions in Kenya. Information Trends 4(2) 1991 91-99. 


\section{Malta}

115. XUEREB, Paul. Professional update session at University. Ghaqda Bibliotekarji No.69/70 1991 1-3.

\section{Netherlands}

116. HARMSEN, Agnes. Bibliotheekwerk voor en door allochtonen: sociale vernieuwing levert in Amsterdan uniek project op. Bibliotheek en Samenleving 19 (7/8) $1991270-272$.

117. KLOCKOW, Jorn and ROTH-PLETTENBERG, Volker. Strukturmodelle fur eine Ausbildung zurn Hoheren Bibliotheksdienst. Bibliotheksdienst 25(3) 1991 334-335.

118. Kwaliteit van beroepsuitoefening niet gediend met verlaging van het opleidingsniveau. Bibliotheek en Samenleving 19(1) 199140.

119. VAN DER STARRE, Jan et al. Aansluiting opleiding beroepspraktijk onderzocht. Open 23(2) 1991 32-40.

New Zealand

120. RICHARDSON, Alan D. Education for information work in New Zealand in the 1990s. Archifacts April 1991 59-63.

\section{Nigeria}

121. GREAVES, Monica. Library education in Nigeria: a comparison of two library schools. Foc.Int.\& Comp.Lib. 22(1) 1991 4-10.

122. OKORO, Okechukwu M. Predjudice and change in librarianship: a critique of library recruitment policies in Nigeria. Int.Lib.Rev. 23(1) 1991 1-9.

Norway

123. Hovedoppaver ved Statens bibliotek- og informasjonshogskole 1990. Synopsis 22(2) 1991 133-135.

124. NERDRUN, Lillo and SELAND, Grete. VUs studenter er VUs kunder. Synopsis $22(3)$ 1991 188-189. 


\section{Pakistan}

125. DANISH, Usman Ahmed. Library education and training in Pakistan. Pakistan Library Bulletin 22(1/2) 1991 5-9.

\section{Poland}

126. BILINSKI, Lucjan. Kwalifikacje zawodowe bibliotekarzy samorzadowych. Bibliotekarz 91991 4-6.

Russia

127. KHOMENKO, G.S. New ways of raising qualification of librarians. Nauch. Tech.Bib.SSSR 1991 (6) 21-23.

128. MUZYKINA E.P. and KUZNETSOV, D.N. School for young library specialists. Nauch.Tech.Bib.SSSR 1991 (2) 36-39.

129. RAYMOND, Boris. Russian education for library and information service. Canadian Library Journal 48(6) 1991 399-404.

130. SOKOLOV, A.V. and AFANANSOVA, L.N. How many and what kind of librarians does Russia need? [In Russian]. Nauch.Tech.Bib.SSSR 1991 (11) 3-11

131. TERESHIN, V.I. Prospects to the library and to the training of specialists for it. Nauch.Tech.Bib.SSSR 1991 (4) 24-28.

\section{South Africa, Republic of}

132. BRINK, J.A. The CUP rationalization programme and the offering of librarianship at universities. SAIBI Nuusbrief 11(6) 1991 5, 7.

133. HORTON, Weldon J. South African librarianship: entering an era of change. Lib.Ass.Rec. 93(1/2) 1991 62, 64.

134. KRUGER, Jan A. Abstracts of Master's theses and Doctoral dissertations in Library and Information Science completed at South African universities, 1983-1990. Mousaion Series 3, 9(2) 1991 17-103.

135. NASSIMBENI, Mary. Closing the North/South gap: education and training of librarians for another South Africa. Educ.Lib.Aus. 8 1/3 1991 5-12 and In Proceedings 57th IFLA General Conference Moscow 1991 (Paper 73-ET-3-E). 
South Pacific

136. WILLIAMS, Helen E. Library education in the South Pacific. J.Educ.Lib.\& Inf.Sci. 31(4) 1991 371-373.

Spain

137. LOZANO, Gomez. La situation des documentalistes en Espagne. Documentaliste 28(1) 1991 41-43.

Sri Lanka

138. KAMALDEEN, S.M. Library education in Sri Lanka. Information Development 7(4) 1991 213-219.

Tunisia

139. BOUAZZA, Abdelmajid and GDOURA, Wahid. Adequation formation/ emploi dans le secteur documentaire en Tunisie. L'Ecluse 3(4) 1991 10-12.

140. DJERAD, Najoua. Formation des documentalistes, bibliothecaires, archivistes et emploi dans les institutions financieres. L'Ecluse 3(2-3) 1991 24-27.

\section{United Kingdom}

141. IRVING, Ann et al. Information UK 2000: manpower, education and training. British Library, 1991. (British Library Research \& Development Report; No.6021)

142. IRVING, Ann. Training 'em young. Advanced Information Report January 1991 7-9.

143. JOHNSON, Ian M., HANNABUSS, C. Stuart and WILDGOOSE, David M. Management education and training for librarians in Scotland. In Proceedings 57th IFLA General Conference Moscow 1991.(Paper 117-PB-7(WS)-E).

144. ROBERTS, Norman. A profession in crisis. Lib.Ass.Rec. 93(7) 1991 450, $452-453$.

145. UK professional resource for library and information science development overseas: a study for the Library and Information Services Council (England). London: British Library and Carpenter Davies Associates, 1991. (British Library Research \& Development Report; No. 6060). 
United States

146. ASSOCIATION FOR LIBRARY AND INFORMATION SCIENCE EDUCATION. Library and information science education statistical report 1991. Sarasota, Fla: ALISE, 1991.

147. AULD, Lawrence. A department with a view. J.Educ.Lib.\& Inf.Sci. 32(3/4) 1991 203-206.

148. BOHANNAN, April. Library education: struggling to meet the needs of the profession. J.Acad.Lib. 17(4) 1991 216-219.

149. BOYKIN, J.F. Library automation 1970-1990: from the few to the many. Lib.Admin.\& Man. 5(1) 1991 10-15.

150. COUNCIL ON LIBRARY RESOURCES. Library schools in research universities. Bull.ASIS 17(3) 1991 19-21.

151. DANIEL, Evelyn H. Education for library and information science In Libraries and Information Services Today, Chicago: ALA, 1991. ISBN 0838905668 pp.97-103.

152. DOUGHERTY, Richard M. Library education: the 1990s. [Editorial]. J.Acad. Lib. 17(3) 1991138.

153. GAUGHAN, Tom. Taking the pulse of library education. American Libraries 22(11) 1991 1020-1021, 1072.

154. HAGEN-LAUTRAP, Carlos B. Advancing by degrees: the road not taken Part II. Inf.Bull.West.Assoc.Map.Lib. 22(2) 1991 97-105.

155. HYMAN, Richard. Library schools in crisis: stemming the tide. Wilson Library Bulletin 65(5) 1991 46-49.

156. KATZER, Jeffrey. A lesson to be learned. Library Quarterly 61(3) 1991 291-292.

157. KOLLASCH, Matthew. An enduring question. Wilson Library Bulletin 65(7) 1991 79-83.

158. MANLY, Will. Professional survival: its academic. Wilson Library Bulletin 65(6) 1991 79-81.

159. PARIS, Marion. Library school closings: the need for action. Library Quarterly 61(3) $1991259-262$.

160. PARIS, Marion et al. Perspectives on the elimination of graduate programs in library and information studies: a symposium. Library Quarterly 61(3) 1991 259-292. 
161. STIEG, Margaret F. The closing of library schools: Darwinism at the university. Library Quarterly 61(3) 1991 266-272.

162. WHITE, Herbert S. Politics, the world we live in. Library Quarterly 61(3) 1991 262-266.

\section{Yugoslavia}

163. CVELJO, K. Professional education and training issues facing library and information science educators. Informatologica Yugoslavica 23(1/2) 1991 47-50.

164. SECIC, D. and STANCIN-ROSIC D. Library and information research in Yugoslavia: prerequisite for its development. Libri 41(4) 1991 51-58.

Zimbabwe

165. PODMORE, E.A. Human resources in libraries in a developing Zimbabwe: a dual thrust. Zimbabwe Librarian 23(1) 1991 19-22.

\section{LIBRARY AND INFORMATION SCIENCE SCHOOLS AND DEPARTMENTS}

\section{General}

166. DETLEFSEN, Ellen Gay \& HUBER, Jeffrey T. AIDS awareness in the LIS classroom and school. J.Educ.Lib.\& Inf.Sci. 32(3/4) 1991 237-239.

167. SPARKS, C. Glenn. An adaptation of strategic planning for schools of library and information science. J.Educ.Lib.\& Inf.Sci. 31(3) 1991 204-233.

168. SPELLER, Benjamin F. Educating black librarians: papers from the 50th anniversary celebration of the School of Library and Information Science, North Carolina Central University. Jefferson, N.C.: McFarland, 1991. ISBN 0899505740.

\section{Accreditation}

169. BERRY, John N. Don't leave it to eductators. Library Journal 116(18) 19916.

170. EVANS, Gwynneth. Library education accreditation: its importance to the Canadian library community. Canadian Library Journal 48(2) 1991 103-107.

171. TOTTEN, H.L. American and Canadian accreditation of library education programmes by the American Library Association. Informatologica Yugoslavica 23(1/2) 1991 51-59. 


\section{Curriculum development}

172. BRINKLEY, R. et al. Designing and producing courseware for distance learning instruction in higher education: a nine step, four element approach. Tech Trends 36(1) 1991 50-54.

173. LARGE, Andrew. Curriculum development: some reflections on Unesco's role. J.Educ.Lib.\& Inf.Sci. 32(1/2) 1991 77-83.

174. VAN DER STARRE, Jan H.E. Curriculum aspects of a teaching module on database construction. Education for Information 9(1) 1991 39-46.

\section{Courses / study - professional}

First qualification

175. CHRISTENSEN, Alfred Gynther. BDI-uddannelserpa hojt niveau. Biblioteksarbejde 321991 5-33.

176. DE SMET, Egbert. De Speciale Licentie Informatie - en Bibliotheekwetenschap: het nieuive curriculum en de opleidings-problematick. Bibliotheek \& Archiefgids 67(1) 1991 1-10.

177. DICKSON, Ian. Bachelor of Applied Science (Technology Management): A partnership between higher education and industry. J.Educ.Lib.\& Inf.Sci. 32(1/2) 1991 13-25.

178. JIPENG, Jing, DUANFANG, Jiang and ZHONGLIAN, Zhang. The postgraduate course in information engineering at Jilin University of Technology (JUT). Education for Information 9(4) 1991 329-336.

179. KIRKHAM, Sandi. Customizing graduate education for information management. J.Educ.Lib.\& Inf.Sci. 32(1/2) 1991 8-12.

180. PAEZ-URDANETA, Iraset. The development of the RGPIS at Simon Bolivar University: learnings and perspectives. J.Educ.Lib.\& Inf.Sci. 32(1/2) 1991 61-68.

181. SAYERS, M.K. and WOOD, F.E. The use and value of M.Sc. Information Studies dissertations. J.Inf.Sci. 17(5) 1991 307-314.

Advanced courses

182. BIGGS, Mary. A perspective on library science doctoral programs. J.Educ. Lib.\& Inf.Sci. 32(3/4) 1991 188-193. 
183. SWIGGER, Keith. Money, sex and reputation in doctoral programs in library science. Coll.\& Res.Lib.News 52(3) 1991 157-161.

184. WHITBECK, George W. Doctoral programs in library and information science: a descriptive study. J.Educ.Lib.\& Inf.Sci. 31(4) 1991 314-328.

185. WHITBECK, George W. Doctoral programs in library and information science: an update. J.Educ.Lib.\& Inf.Sci. 32(3/4) 1991 178-187.

\section{Courses / study - paraprofessional}

186. AINA, L.O. The curriculum and characteristics of information personnel trainees at the middle level in Africa. Int.Lib.Rev. 23(4) 1991 357-364.

187. ALIRE, Camila. Paralibrarians. Colorado Libraries 17(3) 1991 20-21.

188. CANADIAN LIBRARY ASSOCIATION TASK FORCE ON THE PROFESSIONAL REVIEW PROCESS FOR LIBRARY TECHNICIAN PROGRAMS IN CANADA. Guidelines for the education of library technicians. [Ottwa]: Canadian Library Association, 1991.

189. CROSBIE, Sally. Closing address at the Fifth National Library Technicians Conference, 1989. Australian Library Journal 40(2) 1991 112-116.

190. HOLSTE-FLINSPACH, Karin. Assistenten an Bibliotheken und Bibliotheksassistenten: Ausbildungemoglichkeiten fur die mittere berufliche Ebene. Bibliotheksdienst 25(10) 19911514.

191. JOHNSON, Ian M. The development of library technicians: a review of experience in selected countries. IFLA Journal 17(3) 1991 256-265.

\section{Modes of study}

\section{Part-time}

192. WEAVER, Margaret and WILLIAMS, Jean. Part-time: what degree of success? Assistant Librarian 84(7) 1991 100-102.

\section{Distance education}

193. BABU, B. Ramesh and RAO, P. Gangadhara. Master's degree in Library and Information Science through open learning: case study of the University of Madras. Library Review 40(4) 1991 21-26.

194. BARROW, Daniel D. Distance education and the closing of the American library school. Library Quarterly 61(3) 1991 273-282. 
195. BARROW, Dan. Distance education, rural libraries and professional development. Wilson Library Bulletin 65(9) 1991 46-47.

196. BARROW, Daniel. The Library and Information Science Distance Education Consortium: The Profession's Virtual Classroom. Wilson Library Bulletin 66(2) 1991 41-43.

197. DIAMENT, Nic. Le teleenseignement au C.A.F.B.: apres dix-huit mois. Bull.Inf.ABF. No.150 1991 33-35.

198. DOSA, Marta and KATZER, Jeffrey. Electronic networking in support of South-South cooperation. J.Educ.Lib.\& Inf.Sci. 32(1/2) 1991 84-96.

199. HAYCOCK, Richard C. The ICLIS report. J.Educ.Lib.\& Inf.Sci. 32(1/2) 1991 38-43.

200. HAYTHORNTHWAITE, Josephine A. and WHITE, Frances C.P. The role of distance education in library and information studies education. Education for Information 9(4) 1991 305-316.

201. HEALY, James S. Distance library education. Library Trends 39(4) 1991 424-440.

202. HOLMBERG, Borje. Open and distance learning in continuing education. IFLA Journal 17(3) 1991 274-282.

203. MIKA, Joseph J. Distance education: the rural role of the urban library and information science program. Rural Libraries 11(2) 1991 21-26.

204. RICHARDSON, Alan. Distance education in library and information studies in New Zealand. COMLA Newsletter No.71 1991 10-11.

205. ROPER, Fred W. Distance education in library and information science education. IFLA Journal 17(3) 1991 283-288.

\section{Teaching methods}

206. BUSCHMAN, John and CARBONE, Michael. A critical inquiry into librarianship applications of the "New Sociology of Education". Library Quarterly 61(1) 1991 15-40.

207. DESCHATELETS, Gilles, EL HAMDOUCHI, Abdelmoula and SAGNA, Olivier. A mini-international network for the production of Computer Assisted Learning Material. J.Educ.Lib.\& Inf.Sci. 32(1/2) 1991 121-126.

208. DELMAS, Bruno et al. Using and integrating computerized information in the teaching of information sciences. J.Educ.Lib.\& Inf.Sci. 32(1/2) 44-46. 
209. EZOVA, S.A. Psychological tests used for training future librarians. Nauch. Tech.Bib.SSSR 1991 (6) 21-23.

210. IRVING, Ann. Using computers in media studies. CTI Cent.Lib.\& Inf.Studies News 2(4) 1991 21-23.

211. NASRI, William. International studies: how do we serve them? An educator's reflections. J.Educ.Lib.\& Inf.Sci. 32(1/2) 1991 117-120.

212. PATEL, Jashu. Evaluation techniques and methods in library science: a selected review of the literature and a proposed study of the effects of student performance evaluation in library education in UK and USA. Her.Lib.Sci. 30(3/4) 1991 159-167.

213. ROWLAND, Lytton and TSENG, Gwyneth M. Computer methods in the teaching of library and information studies. Education for Information 9(1) 1991 47-54.

214. SANGSTER, A. and WILSON, R.A. Knowledge based learning. Expert Sys.Inf.Man. 4(1) 1991 49-63.

215. Survey of IT in LIS departments in the British Isles. CTI Cent.Lib.\& Inf.Studies News. 2(6) 19912

216. VOROJSKY, F.S. and SHESTOVA, I.G. Systems logic approach to teaching the fundamentals of developing the automated working places of the librarians [In Russian]. Nauch.Tech.Bib.SSSR 1991 (8) 21-24.

\section{Specialised education}

Academic librarianship

217. COUTTS, Margaret M. New professionals - training for the present and the future. Library Review 40(2/3) 1991 9-20.

218. HERUBEL, Jean-Pierre V.M. To "degree" or not to "degree": academic librarians and subject expertise. Coll.\& Res.Lib.News 52(7) 1991437.

219. JONES, William G. The education of academic librarians: how many degrees are enough? Coll.\& Res.Lib.News 52(9) 1991 584-586.

\section{Acquisitions}

220. COHEN, Donna K. The present state of education for acquisition librarianship. Library Acquisitions 15(3) 1991 359-364.

221. FISHER, William. Education for acquisitions: an informal survey. Library Acquisitions 15(1) 1991 29-31. 
222. SCHMIDT, Karen A. The education of the acquisitions librarian: a survey of ARL acquisitions librarians. Lib.Res.\& Tech.Serv. 35(1) 1991 7-22.

Agricultural librarianship

223. JEHL, Maria-Josee. The C.T.A. and international cooperation in the training of agricultural librarians and documentalists. Q.Bull.IAALD 36(1/2) 52-54.

224. MENOU, Michel J. and NIANG, Thiendou. The General Program for Education in Agricultural Information (PROGEFIA): a new global approach to educational development. J.Educ.Lib.\& Inf.Sci. 32(1/2) 1991 97-116.

\section{Art librarianship}

225. ROBERTSON, Jack. Survey of library schools in North America: educational and training opportunities for careers in art libraries and visual resources collections. Art Documentation 10(3) 1991 141-143.

\section{Children's librarianship}

226. BEHRMANN, Christine and VOGLIANO, Dolores. On training the children's reference librarian. Illinois Librarian 73(2) 1991 152-157.

227. Competencies for librarians serving children in public libraries. Emergency Librarian 19(2) 1991 27-28, 30.

228. IMMROTH, B.F. System of education of children's and youth librarians [In Russian]. Bib.i.Bib.Rub. 1991 (129) 87-95.

\section{Conservation and preservation librarianship}

229. CLOONAN, Michele Valerie. Preservation education in American library schools: recounting the ways. J.Educ.Lib.\& Inf.Sci. 31(3) 1991 187-203.

230. LE BITOUZE, Corinne. Conservation et formation a la Bibliotheque nationale. Bull.Inf.ABF. No.152 1991 42-43.

\section{Law librarianship}

231. BONNEY, B. The controversy over dual degrees for law librarians. Leg. Ref. Serv.Q. 11(1/2) 1991 127-133.

232. DUGGAN, James E. Are you now or have you ever been a law librarian?: a look at AALL scholarship recipients, 1967-1988. Law Library Journal 83(2) 1991 363-391. 
233. JOHNSTON, Janis L. Training new law library personnel: the neglected, essential activity. Law Library Journal 83(1) 1991 61-71.

\section{Media librarianship}

234. TURNER, James. Training for audiovisual archivists and librarians. IFLA Journal 17(3) 1991 248-255.

\section{Music librarianship}

235. BINI, Annalisa. The education and training of music cataloguers in Italy. Fontes Artis Musicae 38(1) 1991 68-70.

236. CAROBINE, Timothy. Education and training for music catalogers in the United States. Fontes Artis Musicae 38(1) 1991 61-67.

237. DELCKER-WIRTH, Barbara et al. Lehrbriefe Musik: Begleitmaterialien zur musikbibliothekarischen Ausbildung der Fachhochschule fur Bibliothekswesen, Stuttgart Bd.4 Teil 7 Musikgeschichte. Berlin: Deutsches Bibliothekinstitut, 1991. (dbi materialien 99). ISBN 3870688998.

238. GEERING, Mireille. Le Catalogs de la Musique en Suisse: formation et pratique. Fontes Artis Musicae 38(1) 1991 56-61.

239. GEERING, Mireille, CAROBINE, Timothy and BIBI, Annalisa. Issues in the training of music cataloguers (Symposium). Fontes Artis Musicae 38(1) 1991 56-70.

240. MULLER-BENEDICT, Markus. Lehrbriefe Musik: Begleitmaterialien zur musikbibliothekarischen Ausbildung der Fachhochschule fur Bibliothekswesen, Stuttgart Bd.5 Teil 8 Musikbibliothekarische Berufslehre. Berlin: Deutsches Bibliotheksinstitut, 1991 (dbi materialien, 100).

\section{Public librarianship}

241. BURGERS, Gerda. Profiel van de eigentijdse bibliothecaris: welke kwaliteiten en welk leerprogramma ziin nodig voor actief inlichtingenwerk? Bibliotheek en Samenleving 19(1) 1991 43-44.

\section{School librarianship}

242. BEATTIE, Kate and HENRI, James. Education for teacher-librarianship in Australia. Education for Information 9(4) 1991 317-327. 
Serials librarianship

243. MEISELES, Linda. The do's and don't of serials training. Serials Librarian 19(3/4) 1991 217-219.

244. WOODWARD, Hazel. Training for serials work. Out.Res.Lib. March 1991 10-11.

\section{Teaching individual subjects}

Artifical intelligence

245. WALLACE, F.L. and WALLACE, S.R. An undergraduate course in artifical neural networks. Computers \& Education. 16(2) 1991 153-156.

Bibliographic instruction

246. WHITE, Herbert S. Bibliographic instruction and the library school curriculum. J.Educ.Lib.\& Inf.Sci. 32(3/4) 1991 194-202.

\section{Bibliography}

247. GEARY, James W. Introducing library science students to primary source material. J.Educ.Lib.\& Inf.Sci. 32(1/2) 1991 130-132.

248. METZGER, Andrew J.B. Bibliographical contributions of the students of the Department of Library Studies, University of Zambia. Zambia Lib.Ass.J. 19(1) 1991 30-44.

249. SIMONETTI, Carlo Maria. Funzione propedeutica della bibliografia: ricerca bibliografica e professione bibliotecaria. Biblioteche Oggi 9(5) 605-614.

250. WILLIAMS, L.B. Subject knowledge for subject specialists: what the novice bibliographer needs to know. Collection Management 14(3/4) 1991 31-48.

\section{Bibliotherapy}

251. SMITH, Alice Gullen. Whatever happened to library education for bibliotherapy: a state of the art. In G. McCabe and B. Kriessman eds. Advances in library administration and organization. Greenwich Conn: JAI Press Vol.9 1991 ISBN 1559380667 pp.29-56. 


\section{Content analysis}

252. NOHR, Holger. The training of librarians in content analysis: some thoughts on future necessities. International Classification 18(3) 1991 153-157.

\section{Expert systems}

253. MORRIS, Anne and HUTTON, Susan. Expert systems teaching and research in North American LIS schools. Education for Information 9(2) 1991 107-120.

\section{Information design}

254. LEWIS, David. Information design: resource materials for education and training. [London]: British Library R \& D Department 1991. (British Library Research and Development Report; no.6050).

\section{Information retrieval}

255. BAKER, Betsey, HUSTON, Mary M. and PASTINE, Maureen. Making connections: teaching information retrieval. Library Trends 39(3) 1991 210-222.

256. JOHNSON, Ian M. Teaching online information systems: perspectives on the British experience. IFLA Journal 17(3) 1991 241-247.

\section{Information technology}

257. VAN BRAKEL, Pieter A. Teaching information technology: a challenging task. Electronic Library 9(3) 1991 131-133.

\section{Marketing}

258. YERBURY, Hilary, COOMBS, Merolyn and McGRATH, Robert. Making the transparent visible: an activity to demonstrate some of the concepts of information service and product design. Education for Information 9(2) 1991 129-137.

\section{Reference and information service}

259. FIELDER, Marie and HUSTON, Mary M. Access ability: harnessing knowledge of 'thinking like a searcher'. Library Trends 39(3) 1991 299-315. 
260. TEHNZEN, Jobst. Die theoretische Ausbildung der Bibliotheksrefendare: Umsetzung der Empfehlungen fur die Ausbildung des Hoheren Bibliotheksdiensters an den Ausbildungseinrichtlungen: Referate u Diskussionsgebrusse... am 22 und 23 November 1990 in Frankfurt. Berlin: Deutscher Bibliotheksinstitut, 1991. (dbimaterialen 107. ISBN 3870689072.

\section{Research methods}

261. ALLAN, P. and BENSON, L.D. Computing and qualitative analysis: issues in research methods teaching. In Using computers in qualitative research.London: Sage, 1991. ISBN 080398425 1. pp.75-88

\section{Subject indexing}

262. SCHULZ, Ursula. Einfuhrung in die Grundlagen der inhaltlichen Erschliessung mit BISMAS am Fachbereich BID der FHS Hannover. ABI Technik 11(4) 1991 289-296.

\section{Practical work experience}

263. KEMPER, Beate. Vier Monate Vollzeit: Datenverarbeitung- Fortbildung fur Arbeitslose. Buch u.Bib. 43(6/7) 1991 517-518.

264. LEONARD, Barbara G and PONTAU, Donna Z. Sculpting future libraries through structured practicums: the role of academic librarians. J.Acad.Lib. 17(1) 1991 26-30.

265. LYDERS, Josette Anne and WILSON, Patricia Jane. Field experience in library education: a natural survey. School Library Journal 37(1) 1991 31-35.

266. McAULAY, Karen E. Hosting a library school placement: the pleasures and pitfalls. Per.Train.\& Educ. 8(1) 1991 8-13.

267. NASSIMBENI, Mary. Contribution of an ideal fieldwork programme: a comparison between student and host institution perspective. S.Afr.J.Lib.\& Inf.Sci. 59(2) 1991 145-158.

268. RICE-LIVELY, Mary Lynn. A model for an academic library and library school mentor/protege program. Coll.\& Res.Lib.News 52(3) 1991 163-164.

269. TURCK, Beate. Erste Gehversuche des Vereins zur Forderung bibliothekarischer Auslandpraktika. Buch u.Bib. 43(2) 1991 118-119. 


\section{Teaching staff / faculty}

270. AINA, L. O. Who's who in library and information science training institutions in Africa 1990/1991. Ibadan: Archlib and Information Services, 1991. ISBN 978 3141309.

271. BARNETT, Judith B. Library science educators and the future of the profession: a view from the field. J.Educ.Lib.\& Inf.Sci. 31(3) 1991 254-257.

272. BRUNDIN, Robert E. Field experience and the library educator. J.Educ.Lib.\& Inf.Sci. 31(4) 1991 365-368.

273. CAYNON, William. Satisfaction among faculties of ALA Accredited library schools. J.Educ.Lib.\& Inf.Sci. 31(4) 1991 294-313.

274. European Library/Information Educators form a new association. Library Times International 8(3) 199129.

275. European Library/Information Educators form a new association. Nordinfo Nytt 14(4) 1991 48/49.

276. European Library/Information Educators form a new association. Eur. Res.Lib.Coop. 1(3) 1991 355-357.

277. European Library/Information Educators form a new association. Inform No.140 19912.

278. FUTAS, Elizabeth and ZIPKOWITZ, Fay. The faculty vanishes. Library Journal 116(14) 148-152.

279. GARLAND, Kathleen. The relationship of faculty size to scholarly productivity and quality ranking: implications for education for librarianship. J.Educ.Lib.\& Inf.Sci. 32(3/4) 1991 250-253.

280. HEIM, Kathleen M. and OSTETAG, Keith. Sources of institutional power: an analysis of faculty policy participation as an agent of influence and domain. Library Quarterly 61(3) 1991 282-291.

281. HUNT, Christopher J. Library staff development consultancy: a means to achieve a better library. Per.Train.\& Educ. 8(1) 1991 3-7.

282. KARATYGINA, T.F. and SKVORTSOV, V.V. Organisation and content of post-institutional continuous education of instructors of higher secondary library educational establishments. In Proceedings 57th IFLA General Conference Moscow 1991. (Paper 67-RTCPE-2-R-E).

283. MORAN, Barbara B. Evaluation of faculty in schools of library and information science: an element in educational excellence. J.Educ.Lib.\&Inf.Sci. 32(3/4) 1991 207-215. 
284. MULARSKI, Carol A. Institutional affiliations of authors of research articles in library and information science: update. J.Educ.Lib.\& Inf.Sci. 31(3) 1991 179-186.

\section{Students}

285. BATEMAN, Hilarie and STURGES, Paul. Selection and preparation of research students at DILS Loughborough. Education for Information 9(2) 1991 139-142.

286. BRITZ, J.J. and BOON, J.A. Getal studente in biblioteek- en inligtingkunde aan Suid-Afrikaanse universiteite en technikons: 1987-1991. S.Afr.J.Lib.\& Inf.Sci. 59(3) 1991 204-212.

287. DETLEFSEN, Ellen Gay and OLSON, Josephine E. The librarian and the leaver: who leaves the profession? J.Educ.Lib.\& Inf.Sci. 31(4) 1991 275-293.

288. GENOVESE, Robert. The use of library school students for technical services projects. Technical Services Quarterly 8(4) 1991 63-69.

289. JOSEY, E.J. Recruitment of international students: the Pittsburgh model. J.Educ.Lib.\& Inf.Sci. 32(3/4) 1991 216-221.

290. KNOWLES, Em Claire and JOLIVET, Linda. Recruiting the under represented: collaborative efforts between library educators and library practitioners. Lib.Admin.\& Man. 5(4) 1991 189-193.

291. MAHLMANN, Peter. Bundeskonferenz der Bibliothekstudenten Gesamtdeutsch. Buch u.Bib. 43(1) 1991 13-14.

292. TALLMAN, Julie I. Each one an individual: needs and satisfaction levels of international students in United States library and information science programs. IFLA Journal 17(3) 1991 235-240.

293. TALLMAN, Julie I. International student perceptions of their faculty in U.S. library and information science programs. J.Educ.Lib.\& Inf.Sci. 32(1/2) 1991 47-60.

294. TALLMAN, Julie I. Library and information science programs in the United States: international student perceptions of their academic adaptation process. Int.Lib.Rev. 23(3) 1991 271-285.

\section{Libary and information schools and departments - individual schools}

295. BAZSA, Gyorgy. Kossuth Gondolatok a debreceni Kossuth Lajos Tudomanyegyetemen folyo informatikus- knyvtaros kepzesrol. Tud.Mus.Taj. 38(4) 1991 152156. 
296. BEKKER, J. and ROUX, P.J.A. Centre for Library and Information Service at the University of South Africa: ten years old. Mousaion. Series 3, 9(1) 1991 24-30.

297. BETHERY, Annie. MEDIADIX: un bilan. Bull.Inf.ABF No.150 1991 31-35.

298. BISCHOFF-KUMMEL, Gudrun. 45 Jahre bibliothekarische Ausbilding in Hamburg. Buch u.Bib. 43(2) 1991 115-116 and Bibliotheksdient 25(2) 1991 206-208.

299. BOEHM, Eric H. and HORTON, Forest W. The ISIM Distance learning methodology and the IRM curriculum. J.Educ.Lib.\& Inf.Sci. 32(1/2) 1991 26-37.

300. The closing of the Columbia Library School: a lesson in applied inertia. Library Monitor. No.31 1991 2-6.

301. DOUGLAS, Daphne. One byte at a time: automation in the Department of Library Studies, University of the West Indies. COMLA Newsletter No.73 1991 2, 28-31.

302. A Escola Superior de Conservacao e Restauro. Cad.Bib.Arq.Doc. No.2 1991 149-152.

303. HACKER, Rupert. Bayerische Beamtenfachhochschule, Fachbereich Archivund Bibliothekswesen: Jahresbericht 1990. Bibliotheksforum Bayern 19(1) 1991 84-85.

304. HARKE, Rose. Ausbildungsplan der Stadtbezirksbibliothek Berlin - Marzahn 1990/91. Bibliotheksinfo 1(1) 1991 32-38.

305. KILLENBERG, Harald. Das Konzept der informations- wissenschaftlichen Ausbildung in Ilmenau. Informatik 38(6) 1991 207-208.

306. KRESAKOVA, Jana. Supis diplomovych prac obhajenych na katedre knihovedy a vedeckych informaci FF UK V skolskom roku 1988/89. In Kniznicny zbornik 1991. [s.1.]: Matica Slovenska, 1991. ISBN 8070902094 pp.125-132.

307. LANGELAND, Asbjorn. BRODD - Oppdragsavdelingen ved SBIH. Synopsis 22(2) 1991 104-105.

308. MANDERS, Ingunn. Stiftelsen for informasjonsteknologisk utvikling ved SBIH (STING). Synopsis 22(2) 1991 111-112.

309. MANECKE, Hans-Jurgen. Die Technische Hochschule Ilmenuau/ Thuringen: eine alte (neue) Ausbildungstatte fur Informationfachkrafte. Nach.Dok. 42(1) 1991 $52-53$.

310. MARTIN, William J. Education for information management: restructuring and reform. Education for Information 9(1) 1991 21-28.

311. MAUCH, Bertold. Ein Abkommen der FHB mit Grenoble. Weiterstudieren in Frankreich. FHB Aktuell (1) 1991 2-3. 
312. PLASSMAN, Engelbert. Koln, Fachhochschule fur Bibliotheks- und Dokumentationswesen in Koln: Rektoratsubergabe an der FHBD. Mitt.Verb.Bib.Land. Nord. 41(1) 1991 44-45.

313. PLASSMANN, Engelbert. Ruckblids auf vier Jahre FHBD. Mitt.Verb.Bib. Land.Nord. 41(1) 1991 45-48.

314. Randse Afrikaanse Universiteit. SAIBI-Nuusbrief 11 (1/2) 19919.

315. SIMMONS, Wendy. A history of the University of Botswana Department of Library and Information Studies. J.Educ.Lib.\& Inf.Sci. 32(1/2) 1991 135-137.

316. UMLAUF, Konrad. Verein der Freunde und Forderer der Fachhochschule fur Bibliothekswesen Stuttgart. FHB Aktuell 119916.

317. University of Cape Town. SAIBI Nuusbrief. 11(4) 199113.

318. VODOSEK, Peter. Auslandskontakte Immer mehr Partnerschaften mit der FHB. FHB Aktuell 1199112.

319. VOGELER, Hellmut. Europaische Kooperation in der Ausbildung: Besuch beim Newcastle Polytechnic. FHB Aktuell 119917.

320. WENDT, Harald. Bayerische Bibliothekschule: Jahresbericht. Bibliotheksforum Bayern 19(1) 1991 82-84.

\section{PROFESSIONAL QUALIFICATIONS}

321. ARMSTRONG, Cath. NVQ: What is it? How will it benefit our members? Play Matters Autumn 199116.

322. DAKERS, Hazel. SVQs and NVQs: where are we now and where are we going? Lib.\& Inf.Asst. 4(2) 1991 4-6.

323. GREENWOOD, Linda. Road to... CHARTER: some AAL views and proposals. Assistant Librarian 84(5) 1991 70-71.

324. McARTHUR, Mary. A new Scottish qualification for para-professionals. Lib.\& Inf.Asst. 4(2) 1991 6-7.

325. QUANSICHKA, Janet. National Vocational Qualifications. Lib.\& Inf.Asst. 4(2) $19913-4$.

\section{CAREER DEVELOPMENT}

326. BRIDGLAND, A. Career planning - an educator's perspective. Educ.Lib.Aust. 8(2) 1991 68-71. 
327. DUREY, Peter. The appraisal and professional development of staff in academic libraries. New Zealand Libraries 46(9) 1991 7-9.

328. GROSCH, Mary and WEECH, Terry L. Perceived value of advanced subject degrees by librarians who hold such degrees. Lib.\& Inf.Sci.Res. 13(3) 1991 173-199.

329. HANNABUSS, Stewart. Analysing appraisal interviews. Scottish Libraries No.30 1991 13-15.

330. JANI, Nila, PAREKH, Hersha and SEN, Bharati. Individual perceptions of professional advancement. Libri 41(3) 1991 183-193.

331. KOENIG, Michael E.D. The transfer of library skills to non library contexts. In Irene P. Godden ed. Advances in librarianship. Academic Press, 1991. ISBN 0120246155 pp.1-27.

332. NANKIVELL, Clare. The Class of ' 88 - the National Cohort Study of Newly Qualified Librarians and Information Workers. Interim Report. Birmingham: Centre for Information Research, School of Information Studies, Birmingham Polytechnic, 1991.

333. NANKIVELL, Clare. The Class of ' 88 in isolation. Assistant Librarian 84(12) 1991 189-191.

334. PAUL, Meg. Career planning Part II An employer's perspective. Educ.Lib. Aust. 8(2) 1991 72-77.

335. REAGOR, Melinda. Life beyond library school. New Jersey Libraries 24(3) $19916-8$.

336. RILEY, Gillian. Job exchange in librarianship. Per.Train.\& Educ. 8(3) 1991 49-55.

337. ROBERTS, Norman and KONN, Tania. Librarians and professional status: continuing professional development and academic libraries. London: Library Association. 1991. ISBN 0851574521.

338. ROBSON, Margaret. Flexibility and adaptability: an overseas public library staff exchange. Aust.Pub.Lib. 4(2) 1991 82-84.

339. SEPTEMBER, Peter E. Career planning as a personnel function: its importance in academic libraries. J.Lib.Admin. 14(4) 1991 51-68.

340. TAYLOR, A.B. Continuing professional development for library and information science staff in the South West: report for the year October 1990-September 1991. Bath: The Library, University of Bath, 1991.

341. WAINWRIGHT, Eric J. Job satisfaction and professional development: congruent and achievable goals? Educ.Lib.Aust. 8(2) 1991 60-67. 
342. WEBB, S.P. Best practice: continuing professional development for library/ information staff in UK professional firms. London, British Library R\&D Department, 1991. (British Library Research and Development Report; No.6039). ISBN 0 951776104 .

343. WEINGAND, Darlene E. The continuum of library education: maintaining competence through the professional worklife. IFLA Journal 17(3) 1991 266-273.

\section{CONTINUING EDUCATION}

344. ALEMNA, A.A. Continuing education for librarians in Ghana: problems and expectations. IFLA Journal 17(3) 1991 303-309.

345. AUSTRALIAN LIBRARY AND INFORMATION ASSOCIATION. School Libraries Section. National Committee. Continuing professional education for people outside the metropolitan area: a discussion paper. Orana 27(2) 1991 82-94.

346. Continuing education for library and information workers: brighter prospects ahead in Papua New Guinea. ET Newsletter No.12 1991 [1-2].

347. DREYER, Libby. Resource centres, training and extending information services: the Community Resource Centre Training Project. Innovation 2 June 1991 22-24.

348. ERKKILA, John and ERKKILA, Margaret. Learning by others' experience: An analysis of Library Journal cases 1983-1989. Education for Information 9(4) 1991 269-283.

349. ETTINGER, Linda F. The Applied Information Management program: multidisciplinary continuing higher education. Education for Information 9(1) 1991 29-38.

350. EVANS, John. Continuing education for library and information workers in Papua New Guinea - a review of plans and practice. Educ.Lib.Aust. 8 1/3 1991 13-19.

351. Guidelines for the development of post-appointment and continuing education and training programmes. Archivaria 31 Winter 1990/1991 60-89.

352. HARRIS, Carolyn L. and LEWIS, David W. The Columbia University Libraries Staff Development Seminar. J.Acad.Lib. 17(2) 1991 71-73.

353. HERMAN, Nadine. La formation continue. Seminaire de Chalon-sur-Saone Juin 1991. Bull.Inf.ABF No.152 1991 14-15.

354. HOHN, Thomas. Bibliothekarische Fortbilding im Wandel. Bibliothek: Forschung u. Praxis. 15(2) 1991 189-233. 
355. HUTTEMANN, Lutz. Continuing education programmes for library and information personnel: papers and proceedings of the Information Experts' Meeting held in Harare Zimbabwe 25-29 June 1991. Bonn: Deutsche Stiftung fur Internationale Entwicklung, 1991.

356. LEWINS, Helen, MACDOUGALL, Jennifer and TSENG, Gwyneth. Continuing education and professional staff in United Kingdom university and polytechnic libraries. Brit.J.Acad.Lib. 6(1) 1991 27-35.

357. LEWINS, Helen, MACDOUGALL, Jennifer and TSENG, Gwyneth. Participation, benefits and defects of UK continuing education and training opportunities in librarianship and information science. Per.Train. \& Educ. 8(2) 1991 31-37.

358. LEWINS, Helen, MACDOUGALL, Jennifer and TSENG, Gwyneth. Public libraries and their continuing education. Public Library Journal 6(2) 1991 43-46.

359. MACHNIK, Monika. Zeit oder Un-Zeit fur Weiterbildung? Bibliotheksinfo 1(5) 1991 298-299.

360. MAKINEN, Riitta. Continuing professional education on the management of change in academic and research libraries. IFLA Journal 17(3) 1991 289-294.

361. MARTYNOVA, L.S. The continuous education system at the training centre of the V.I, Lenin State Library. In Proceedings 57th IFLA General Conference Moscow 1991. (Paper 66-RTCPE-1-R+E).

362. NAWE, Julita. Need and priority areas for continuing education for sub and professional information, library and archives personnel in Tanzania. IFLA Journal 19(3) 1991 310-314.

363. NEWMAN, G. Charles, DIBARTOLO, Amy L. and HILL, Levirn. Fostering professional growth in academic libraries: a case study for the 1990s. Lib.Admin.\& Man. 5(1) 1991 41-44.

364. NICHOLSON, Fay and BRIDGLAND, Angela. Continuing education: an Australian perspective. IFLA Journal 17(3) 1991 295-302.

365. PUSKOVA, S.V. Continuing education of librarians in the USA. [In Russian] Bib.i.Bib.Rub. 1991 (128) 60-71.

366. RAJU, A.A.N. Planning for professional advancement programmes in library and information science. Her.Lib.Sci. 30(3-4) 1991 167-174.

367. SLATER, Margaret. Seminars, conferences etc.: provision and providers. Lib.Ass.Rec. 93(3) 1991139.

368. SLATER, Margaret. Training provision through professional events. Journal of Information Science 17(3) 1991 175-184. 
369. SMITH, Duncan and BURGIN, Robert. The motivations of professional and paraprofessional librarians for participating in continuing education programs. Lib.\&Inf.Sci.Res. 13(4) 1991 405-429.

370. TREVETT, Melissa. The Professional Development Program. J.Acad.Lib. 17(2) 1991 73-75.

371. WATSON, Elizabeth. After the degree: continuing education for Commonwealth Caribbean librarians. COMLA Newsletter No.73 1991 3-5, 32-34.

372. WEINGAND, Darlene E. Changing marketplace. [Continuing education column. J.Educ.Lib.\& Inf.Sci. 31(4) 1991 369-370.

373. WEINGAND, Darlene E. Continuing education for the many (not just the few). J.Educ.Lib.\& Inf.Sci. 32(1/2) 1991 133-134.

374. WEINGAND, Darlene E. Second class citizen? J.Educ.Lib.\& Inf.Sci. 32(3/4) 1991 240-241.

375. WOOLLS, Blanche. Continuing professional education: an IFLA guidebook. Munchen: Saur, 1991. (IFLA publication; 55). ISBN 3598217846.

\section{TRAINING}

\section{General}

376. BAKER, D. Training for management in libraries. London: Library Association, 1991. (Guidelines for training in libraries; 9). ISBN 0853656096.

377. EZELL, Charlaine and McMAHON, Patrick. Don't count on clairvoyance: a librarian and an independent consultant plan a staff training workshop. Wilson Library Bulletin 66(3) 1991 33-37.

378. HOFFMAN, Ellen. Training issues in management of information services in an advanced technological world. In A.H. Helal and J.W. Weiss eds. Information Technology and Library Management 13th International Essen Symposium. Essen: Universitatsbibliothek Essen, 1991.ISBN 092260214 2, pp.51-64.

379. INTNER, Sheila S. A field test of the Library of Congress Training the Trainer course. Education for Information 9(3) 1991 225-247.

380. LAFON, Bernard and LARBRE, Francois. La formation: du pret-a porter au sur mesure. Bull.Bib.France. 36(3) 1991 217-221. 
381. NICHOLSON, Howard. Staff development: getting it done. Per.Train.\& Educ. 8(3) $199165-68$.

382. PARRY, Julie. Training Needs Assessment (TNA): its place in an effective training programme. Learning Resources Journal 7(3) 1991 62-66.

383. REDFERN, Margaret. Who is doing what to whom... why... where and how? An Leabharlann Second Series, 8(2) 1991 48-57.

384. PRYTHERCH, Ray ed. Handbook of library training practice Vol.2. Aldershot: Gower, 1991. ISBN 0566036339.

385. SLATER. M. Investment in training: a quick, qualitative conspection in the library - information field. London: British Library R\&D Department, 1991. (British Library Research and Development Report; no.6048).

386. TRASK, Margaret. Do management training courses change managerial behaviour? New Zealand Libraries 46(12) 1991 3-8.

387. WARE, R. Twenty training predictions for the 90s. Information Executive 4(1) 1991 43-45.

\section{Specialised}

388. ALBRITTON, Rosie L. Assessing early outcomes of the Intern-Scholar Program at the University of Missouri-Columbia. J.Acad.Lib. 17(2) 1991 77-78.

389. AMERICAN LIBRARY ASSOCIATION. Reference and Adult Services Division. Interlibrary Loan Committee. Subcommittee on Education and Training. Interlibrary loan training and continuing education: model statement of objectives. RQ 31(2) 1991 177-184.

390. ARMSTRONG, C.J. New approaches in the training and education of online users. Online Review 15(3/4) 1991 147-171.

391. BAKKE, Celia. Training of technical services staff in the automated environment. Washington D.C.: Association of Research Libraries Office of Management Services, 1991. (SPEC Kit; 171).

392. BERWIND, Anne May. Orientation for the reference desk. Ref.Serv.Rev. 19(3) $199151-54,70$

393. BROWN, Stephen. Its for you: CD-ROM-XA in training. In Raitt, D.E. ed. Online Information '91. Oxford: Learned Information, 1991. ISBN 090493379 2. pp 175-182. 
394. BUGG, Louise M. and WECKER, Charlene D. Training and user services to implement a shared local system: the DALNET experience. Resource Sharing and Information Networks. 6(2) 1991 97-118.

395. CHIU, Joseph Jeong-Yeon. Staff training for information retrieval with particular reference to library online and CD-ROMs service. Thesis M.Lib: University of Wales, 1991.

396. CLEMENS, Bonnie J. and TREVVETT, Melissa. Integrating new professionals into large academic libraries: a symposium. J.Acad.Lib. 17(2) 1991 68-78.

397. CLEMENS, Bonnie J. The Internship Program at the University of Georgia. J.Acad.Lib. 17(2) 1991 75-77.

398. COMMINGS, Karen. Ongoing training for integrated library automation systems. Computers in Libraries 11(10) 1991 42-43.

399. CORE, Jane K. Non professional training and development: organisational purpose and individual satisfaction in the small college library. Per.Train.\& Educ. 8(1) 1991 14-27.

400. CROOK, Alison. Organisational change and its management. Educ.Lib.Aust. 8(2) 1991 10-17.

401. DAVENPORT, Elisabeth and CRONIN, Blaise. The virtual apprentice. J.Inf.Sci. 17(1) 1991 65-70.

402. FEATHER, John. Staff training for preservation. Cad.Bib.Arq.Doc. No.2 1991 153-161.

403. FEGLEY, Linda R. Training for service. Library Work 14 December 1991 6, 8.

404. FEITCH, Deborah and RANKKA, Kristine. Staff training for an online public catalog: a practical approach. Library Software Review 10(1) 1991 3-8.

405. GOULDING, Mary. Real librarians dont play "Jeopardy". Illinois Libraries 73(2) 1991 140-146.

406. GREENBERG, Evelyn. Computer based training: a library circulation model utilizing Hypercard. In E.M. Nelson ed. Computers in Libraries 91. Proceedings of the 6th Annual Computers in Libraries Conference. London: Meckler, 1991. ISBN 088736753 4. pp 57-79.

407. GYESZLY, Suzanne D. and HARER, John B. Replacement of automated systems: organizational and staff training considerations. J.Lib.Admin. 14(1) 1991 $87-115$.

408. HEPWORTH, John B. Training staff and end-users for automated retrieval systems in the health sciences. Education for Information 9(2) 1991 97-106. 
409. HUGHES, Alan. Training for online searching by satellite. ITs News No.24 1991 15-16.

410. HYMAN, Mike. A software suppliers view of training and support - can you really survive without them? Library Micromation News No.31 1991 9-11.

411. ISENSTEIN, Laura J. On the road to STARDOM: improving reference accuracy. Illinois Libraries 73(2) 1991 146-151.

412. KHARITONOV, R.P. Improving the professional skill of specialists occupied in the field of information provision with product guides. [In Russian]. Nauch.i. Tech.Bib.SSSR 1991 (2) 33-56.

413. LATHAM, Joyce M. PC management in a multicounty environment. Computers in Libraries 11(3) 1991 39-40.

414. LOW, Kathleen. Computers, libraries, staff development and training: a symbiotic relationship. In E.M. Nelson, ed. Computers in Libraries 91. Proceedings of 6th Annual Computers in Libraries Conference. London: Meckler, 1991. ISBN 088736 7534 pp 101-103. Also in Information Today 8(2) 1991 38-39.

415. MARCUM, Deanna. CLR's “Internships for Recent Graduates" Program. J.Acad.Lib. 17(2) 1991 69-70.

416. MARKS, Kenneth E. and NIELSEN, Steven. Local area networks: Training and LANS: part one. Computers in Libraries 11(1) 1991 8-9.

417. McAULAY, Karen E.... but how do I tell them? Per.Train.\& Educ. 8(3) 1991 56-64.

418. McLEOD, Pat. Media vs the MLS. New Jersey Libraries 24(3) 1991 8-9.

419. METZ, Ray E. Mounting CD-ROM products on a campus network: site licenses, training and evaluation. In Proceedings of the 12th National Online Meeting 7-9 May New York. Medford, NJ: Learned Information, 1991. ISBN 093873451 2. pp.271-273.

420. MEZHINENE, A.A. and PROKOPCHIK, M.A. Computer aided training at the Vilnius University.[In Russian]. Nauch.Tech.Bib.SSSR 1991 (3) 23-27.

421. MORTON, Margaret L. Training for a changing environment: the challenges in a decentralized system. Q.Bull.IAAIS 36(1/2) 1991 133-135.

422. NILES, Nancy and JACOBSON, Trudi E. Teaching critical thinking in libraries: a continuing education course. Research Strategies 9(4) 1991 198-201.

423. NWALI, L.O. Staff development for computerisation: an account of Abubakar Tafawe Balewa University Library Bauchi. Library Management 12(3) 1991 13-18. 
424. ODINI, Cephas. Training in interpersonal skills for librarians and information workers. Library Review 40(4) 1991 6-20.

425. PARK, Amey. Automation training for remote sites. Computers in Libraries 11(1) 1991 10-11.

426. PETROWSKI, Mary Jane and WILSON, Lizabeth A. Avoiding horror in the classroom: in-house training for bibliographic instruction. Illinois Libraries 73(2) 1991 180-190.

427. PHILLIPS, Anne. Training for bibliographic verification in interlibrary loan. Illinois Libraries 73(2) 1991 175-179.

428. PREECE, Barbara G. and GLASS, Betty J. The online catalog and staff training. Library Software Review 10(2) 1991 100-104.

429. SHEBLE, Mary Ann and HILL, Debra W. Student internships in the catalog department at the University of Alabama Libraries. Southeastern Librarian 41(4) 1991 111-114.

430. SMITH, David R. The characteristics, use and training of reference nonprofessionals in selected south-eastern urban public libraries. Champaign Ill.: University of Illinois Graduate School of Library and Information Science, 1991. (Occasional papers/University of Illinois GSLIS, No.190).

431. STABLER, Karen. A model for training academic librarians on CD-ROM. In M.E. Williams, ed. National Online Meeting 1991. Proceedings of the 12th National Online Meeting New York 7-9 May 1991. Medford N.J.: Learned Information, 1991. ISBN 093873451 2. pp.361-365.

432. STERN. David. Local databases and training. Illinois Libraries 73(2) 1991 161-174.

433. STUBLEY, Peter, LESLIE, Michael and UMNEY, Darren. Designing a multimedia staff training package for librarians. In D.E.Raitt ed. Online Information 91 Proceedings 15th International Online Information Meeting. Oxford: Learned Information, 1991. ISBN $0904933792 \mathrm{pp}$ 167-174.

434. SYKES, Phil. Automation and non-professional staff: the neglected majority. Library Management 12(3) 1991 4-12.

435. WHISLER, Karen. ILLINET online training: a historical perspective. Illinois Libraries 73(2) 1991 157-160.

436. WITTHUS, Rutherford W. Using the Model Statement of Objectives for Academic Bibliographic Instruction to develop learning objectives for academic library interns. Colorado Libraries 17(4) 1991 24-25. 
437. WRIGHT, C. and FRIEND, L. A mobile online/CD-ROM workstation for demos and instruction. Online 15(3) 1991 74-76.

\section{ROLE OF ASSOCIATIONS AND SOCIETIES IN LIBRARY EDUCATION}

438. ARMSTRONG, Christine, RAMBERAN, Kate and BLACKWELL, K.G.B. Professional associations and training. In Libraries and 1992. Library Management 12(1) 1991 26-29.

439. ASSOCIATION FOR LIBRARY AND INFORMATION SCIENCE EDUCATION. Directory of the Association for Library and Information Science Education 1991-92. J.Educ.Lib.\& Inf.Sci. 32(5) 1991 Whole issue.

440. CASTELYN, Mary. Affiliated membership: land of cream and honey. Per. Train.\& Educ. 8(2) 1991 38-43.

441. DAVIS, Donald G. Seventy five years of education for the profession: reflections on the early years. J.Educ.Lib.\& Inf.Sci. 32(3/4) 1991 157-177.

442. DIOP, Amadou. Le Marketing de l'Unite de formation en techniques documentaire a L'IPD/Sahel. L'Ecluse 3(4) 1991 16-20.

443. ERICKSON, Ana Maria Paz de. Contribucion de AIBDA al desorrollo profesional, a traves. Revista AIBDA. 12(2) 1991 29-44.

444. FANG, Josephine Riss and NAUTA, Paul. IFLA's contribution to education for library and information science. IFLA Journal 17(3) 1991 229-231.

445. FERGUSON, S. Library associations and the advancement of librarianship in developing countries. IFLA Journal 17(1) 1991 63-71.

446. FID New professional programme for the 1990s. FID News Bulletin 41(5) 1991 95-97.

447. FID Special Interest Group on Roles, Careers and Development of the Modern Information Professional. FID News Bulletin 41(7/8) 127-128.

448. GODWIN, Mary Jo. ALISE explores the elements for educational excellence. Wilson Library Bulletin 65(7) 1991 51-52.

449. INTERNATIONAL FEDERATION OF LIBRARY ASSOCIATIONS. Continuing Professional Education Round Table. Annual report 1989/90. In IFLA Annual 1990. Proceedings of the 50th General Conference Stockholm 1990, Munchen: Saur, 1991. ISBN 3598206712 pp.181-182. 
450. INTERNATIONAL FEDERATION OF LIBRARY ASSOCIATIONS. Education and Training Section. Annual report 1989/90. In IFLA Annual 1990. Proceedings of the 56th General Conference Stockholm, 1990. Munchen: Saur, 1991. ISBN 359820671 2. pp 119-120

451. LESSING, C.J.H. Bydrae van die Suid-Afrikaanse Biblioteekvereniging (1930-1980) tot biblioteekontwikkeling in Suid-Afrika. S.Afr.J.Lib.\& Inf.Sci. 59(2) 1991 123-134.

452. PARR, Ed. Course recognition: a new approach for a new association. Australian Library Journal 40(2) 98-111.

453. SCHEELE, Jurgen. Fortbildungskommission des Deutschen Bibliotheksinstituts. Bibliotheksdienst 25(5) 1991 719-721.

\section{EDUCATION AND TRAINING FOR RELATED OCCUPATIONS}

454. ALEXANDRE, Jean-Louis. Profession restaurateur. Bull.Inf.ABF. No.152 1991 40-41.

455. BOWES, Roger. Expanding the information horizon: alternative careers for information professionals. Aslib Proceedings 43(9) 1991 271-275.

456. DESSOLIN-BAUMANN, Sylvie. L'archiviste d'enterprise: portrait d'un homme nouveau. Gazette des Archives. No.154 1991 147-176.

457. DUNHILL, Rosemary and SHORT, Cynthia. The training of archivists 1970-1990; an overview. J.Soc.Arch. 12(1) 1991 42-50.

458. KESSLER, Benjamin. Professional qualifications: establishing a bottom line. In Art Libraries Society of North America 1991 Annual Conference. Abstracts of proceedings. [S.l.: ARLIS/NA, 1991]. Session on professional issues for visual resource curators. p.4.

459. LARIBEE, J.F. and LARIBEE, S.F. Information resources management education: IS managers' and educators' views. Inf.Res.Man.J. 4(4) 1991 28-38.

460. LERIN, Varda. Audiovisuel: les formations existantes. Bull.Inf.ABF. No.152 1991 44-45.

461. McRAE, Linda. An analysis of our status as professionals: recommendations for change. In Art Libraries Society of North America 1991 Annual Conference. Abstracts of proceedings. [S.1.: ARLIS/NA, 1991] Session on professional issues for visual resource curators. p.3.

462. WOLFF-TERROINE, Madeleine. Courtier en information: un metier d'avenir? Documentaliste 28(6) 1991 269-272. 


\section{EMPLOYMENT MARKETPLACE}

463. ASSOCIATION OF INDEPENDENT INFORMATION PROFESSIONALS. National survey of members. Infomediary 5(2/3) 1991 135-140.

464. BACON, Alison. Far from happy returns. Assistant Librarian 84(11) 1991 164-165.

465. BELLING, Michael and KERZINGER, Uwe. Berufliche Situation der Fachhochschul- Absolventen: Ergebnisse einer Befragung des Abschlussjahrganges, 1989. Bibliotheksdienst 25(9) 1991 1397-1409.

466. BRAY, F. and TURNER, C. Monitoring the library and information workforce. London: British Library, 1991. (British Library research papers; 97). ISBN 0 712332596 .

467. BRIMISEK, T.A. Washington D.C. special library job requirements: an analysis of Washington Post job advertisements 1983-1989. Special Libraries 82(1) 1991 12-18.

468. BRUYNS, Ruud and SCHIPPER, Irene. Uitzicht op zinvolle baan uiterst gering: de arbeidsmarkt van bibliothecarissen en documentalisten; een analyse en prognose. Bibliotheek en Samenleving 19(3) 1991 111-114.

469. BUSCH, Nancy. Future staffing requirements: some considerations. Wilson Library Bulletin 65(9) 1991 43-45.

470. CALVERT, Philip J. The emerging market for librarians and information workers in New Zealand. New Zealand Libraries 46(9) 1991 9-12.

471. DETLEFSEN, Ellen Gay, OLSON, Josephine K. and FRIEZE, Irene Hanson. Women and librarians: still too far behind. Library Journal 116(5) 1991 36-42.

472. DUCKITT, Pauline. Information professionals in the year 2000. State Librarian 39(1) $19917-10$.

473. DUNSTAN, Neil. Recruitment in the 90s. Aslib Information 19(1) 19919.

474. EDWARDS, Jean-Marc and HACHE, Nicole. Demain, la bibliotheconomie. Argus 20(1) 1991 3-4.

475. EDWARDS, Roderick. Surviving the skills shortage: equal opportunities in recruitment selection. Library Management 12(2) 1991 4-14.

476. HARTSE, M., RAWAN, A. and SCANLAND, R. The evolution of affirmative action at the University of Arizona Library. Coll.\& Res.Lib.News. 52(1) 1991 7-11. 
477. HEIN, Kathleen M. and PERRAULT, Anna H. Gender-based factors contributing to the selection of university administrators. J.Educ.Lib.\& Inf.Sci. 32(3/4) $1991222-231$.

478. McKEOWN, Tom. Industrial issues. Educ.Lib.Aust. 8(2) 1991 29-33.

479. MORRIS, Beryl. What price the woman returner? Library Management 12(2) $199120-22$.

480. PARKER, Sandra. All men are equal (but what about the rest of us). Assistant Librarian 48(6) 1991 84-87.

481. STANYON, Mary. Flexibility: a threat or a promise for women in the library profession? New Library World 92(1087) 1991 4-5.

482. THOMPSON, Verena. Recruitment of library workers from black communities. Library Management 12(2) 1991 15-19. 


\section{NAME INDEX}

AAL see Association of Assistant Librarians AALL see American Association of Law Librarians

Abubakar Tafawa Balewa University Library, Bauchi, 423

ACRL see Association of College and Research Libraries

Adimorah, E.N.O., 045

Afanasova, L.N., 130

African Regional Centre for Information Science, 046

Ahmad, N., 050

AIBDA see Associacion Interamericana de $\mathrm{Bi}$ bliotecarios y Documentalistas Agricolas

Aina, L.O., 186, 270

Aiyepeku, W.O., 046

Albritton, R.L., 388

Alemna, A.A., 100-102, 344

Alexandre, J-L., 454

Algemene Hogeschool Amsterdam, Faculteit Informatie en Communicatie, 174

Ali, S.N., 003

ALIA see Australian Library and Information Association

Alire, C., 187

ALISE see Association for Library and Information Science Education

Allan, P., 261

Amat, N., 012

American Association of Law Librarians, 232

American Library Association, 007, 171

American Library Association. Reference and Adult Services Division. Interlibrary Loan Committee. Subcommittee on Education and Training, 389

American Society for Information Science. 53rd Annual Meeting, Toronto, (1990), 011, 027

Antwerp University, 176

Apostle, R., 052

ARLIS/NA see Art Libraries Society of North America

Armstrong, C., 321, 438
Armstrong, C.J., 390

Art Libraries Society of North America. Annual Conference, (1991), 458, 461

ASIS see American Society for Information Science

Associacion Interamericana de Bibliotecarios y Documentalistas Agricolas, 443

Association for Library and Information Science Education, 146, 439, 441, 448

Association of Assistant Librarians, 323

Association of College and Research Libraries, 436

Association of Independent Information Professionals, 463

L'Association Panafricain pour le Developpement-Sahel, 442

Asundi, A.Y., 105

Auld, L., 147

Australian Library and Information Association, 452

Australian Library and Information Association. School Libraries Section. National Committee, 345

Avison, D.E., 013

Babu, B.R., 193

Bacon A., 464

Baker, B., 255

Baker, D., 376

Bakke, C., 391

Baltimore County Public Library. Staff Trained for Accurate Reference Service Program, 411

Barnett, J.B., 271

Barron, D.D., 194-196

Bateman, H., 285

Baumann, S. Dessolin see Dessolin-Baumann, S.

Bayerische Beamtenfachhochschule. Fachbereich Archiv- und Bibliothekswesen, 303

Bayerische Bibliotheksschule, 320

Bazsa, G., 295

Beattie, K., 242

Becker, J., 296

Behrmann, C., 226 
Belling, M., 465

Benedict, M. Muller see Muller-Benedict, M.

Benson, L.D., 261

Bernhard, P., 002

Berry, J.N., 014, 169

Bertrand, A-M., 065

Berwind, A.M., 392

Bethery, A., 066, 297

Bibliotheque Nationale (France), 230

Biggs, M., 016, 182

Bilinski, L., 126

Bini, A., 235, 239

Birmingham Polytechnic. School of Information

Management, 179

Birmingham Polytechnic. School of Information

Management. Centre for Information Research, 332, 333

Bischoff-Kummel, G., 298

BISMAS, 262

Bitouze, C. Le see Le Bitouze, C.

Blackwell, K.G.B., 438

Boehm, E.H., 299

Bohannon, A., 148

Bonnardel, A-F., 067

Bonney, B., 231

Boon, J.A., 286

Bosc, C., 068

Bouazza, A., 139

Boulbet, G., 069

Bowes, R., 455

Boye, M.I.S., 103

Boykin, J.F., 149

Brakel, P.A. van see Van Brakel, P.A.

Brambilla, R., 107, 108

Bray, F., 466

Brethes, J-P., 070

Bridgland, A., 326, 364

Brimisek, T.A., 467

Brink, J.A., 132

Brinkley, R., 172

Bristol Polytechnic. Library, 382

Britz, J.J., 286

BRODD see Norwegian School of Library and Information Science. Department of Consultancy and Research

Brown, S., 393

Bruin, $H$. de see De Bruin, $H$.

Brundin, R.E., 272

Bruyns, R., 468

Bugg, L.M., 394
Bundeskonferenz der Bibliothekstudenten, (1990), 291

Burgess, G., 241

Burgin, R., 369

Busch, N., 469

Buschman, J., 206

C.A.F.B. see Certificate d'Aptitude Fonctions de Bibliothecaire (France)

Calvert, P.J., 004, 470

Canadian Archivists Education Committee, 351

Canadian Library Association. Task Force on the Professional Review Process for Library Technician Programs in Canada, 188

Carbone, M., 206

Carmichael, J.V., 005

Carobine, T., 236, 239

Castelyn, M., 440

Cava, O.D. see Della Cava, O.

Caynon, W., 273

CD-ROM-XA, 393

Certificate d'Aptitude Fonctions de Bibliothecaire (France), 084

Chiu, J. J-Y., 395

Christensen, A.G., 175

Chu, C.M., 006

Clark, A.J., 001

Clausen, H., 054

Clemens, B.J., 396, 397

Cloonan, M.V., 229

CLR see Council on Library Resources

Clyde, L.A., 104

Cohen, D.K., 220

Columbia University. School of Library Service, 300

Columbia University. School of Library Service. Library, 007

Columbia University Libraries Staff Development Seminar, 352

Comenius University (Bratislava). Department of Library and Information Science, 306

Commings, K., 398

Commission Formation Elementaire de l'ABF, 082 Commission Pedagogique Nationale des Centres Regionaux de Formation aux Carrieres des Bibliotheques du Livre et de la Documentation, 075

Committee of University Principals (South Africa), 132

Computers in Libraries '91, 406, 414 
Computers in Teaching Initiative. Centre for Library and Information Studies, 213

Coombs, M., 258

Core, J.K., 399

Council on Library Resources, 150, 415

Coutts, M.M., 217

Cronin, B., 017, 401

Crook, A., 400

Crosbie, S., 189

CTA see Technical Centre for Agricultural and Rural Cooperation

CTI see Computers in Teaching Initiative

Cveljo, K., 163

Dakers, H., 322

Daniel, E.H., 151

Danin, A., 110

Danish, U.A., 125

Danmarks Bibliotekskole, 054, 055, 175

Davenport, E., 401

Davis, D.G., 441

De Bruin, H., 018

De Smet, E., 051, 176

Delcker-Wirth, B., 237

Della Cava, O., 007

Delmas, B., 208

Demadre, A-M., 071

Denver Public Libraries, 403

Der Starre, J. van see Van der Starre, J.H.E.

Deschatelets, G., 207

Dessolin-Baumann, S., 456

Detlefsen, E.G., 166, 287, 471

Deutschen Bibliotheksinstituts. Fortbildungskommission, 453

Diament, N., 197

Dibartolo, A.L., 363

Dickson, I., 177

Diop, A., 442

Direction du Livre et du Lecture (France). Bureau de la Formation, 089

Distance Technical Assistance, 198

Djerad, N., 140

Dosa, M., 198

Dougherty, R.M., 152

Douglas, D., 301

Dreyer, L., 347

Duanfang, J., 178

Duckitt, P., 472

Duggan, J.E., 232

Dunhill, R., 457
Dunstan, N., 473

Durey, P., 327

East Carolina University. Department of Library and Information Studies, 147

L'Ecole National Superieure des Bibliothecaires, 083

Edwards, J-M., 474

El Hamdouchi, A., 207

Erickson, A.M. Paz de, 443

Erkkila, J., 348

Erkkila, M., 348

Escuela Superior de Conservacao o Restauro, (Lisbon), 302

Essen Symposium, (13th, 1990), 378

Ettinger, L.F., 349

EUCLID see European Association for Library and Information Education and Research

European Association for Library and Information Education and Research, 057, 274-277

Evans, G., 170

Evans, J., 019, 350

Evans, R., 475

Ezell, C., 377

Ezova, S.P., 209

Fachhochschule fur Bibliotheks- und Dokumentationswesen, Koln, 312, 313

Fachhochschule fur Bibliothekswesen, Stuttgart, 237, 240,311, 316, 318, 319

Fachhochschule Hamburg. Fachbereich Bibliothekswesen, 298

Fachhochschule Hannover. Fachbereich BID, 262

Fang, J.R., 444

Feather, J., 402

Fegley, L.R., 403

Feja, D. Rusch- see Rusch-Feja, D.

Ferguson, S., 445

Fetch, D., 404

FID see International Federation for Documentation

Fielder, M., 259

Fisher, W., 221

Fitzgerald, G., 013

Flinspach, K. Holste- see Holste-Flinspach, K.

Fontaine, F., 002

Forgionne, G.A., 020, 021.

Friend, L., 437

Frieze, I.H., 471

Funk, R., 093 
Futas, E., 278

Garland, K., 279

Gasc, M., 073

Gaughan, T., 153

Gdoura, W., 139

Geary, J.W., 247

Geering, M., 238, 239

General Programme for Training in Agricultural Information (PROGEFIA), 223

Genovese, R., 288

Gikenye, M.W., 113

Gintrand, P., 074

Girard, C., 075

Glass, B.J., 428

Gleyze, A., 076

Goasguen, J., 077

Godden, I.P., 016

Godwin, M.J., 448

Goulding, M., 405

Greaves, M., 121

Greenberg, E., 406

Greenwood, L., 323

Grosch, M., 328

Grosser, K., 022

Guyot, B., 078

Gyeszly, S.D., 407

Hache, N., 474

Hacker, R., 303

Hagen-Lautrap, C.B., 154

Hamdouchi, A. El. see El Hamdouchi, A.

Hannabuss, C.S., 143

Hannabuss, S., 329

Harer, J.B., 407

Harke, R., 304

Harmsen, A., 116

Harris, C., 008

Harris, C.L., 352

Hartmann, C., 093

Hartse, M., 476

Haycock, R.C., 199

Haythornthwaite, J.A., 200

Healy, J.S., 201

Hecquard, F., 079-081

Heim, K.M., 280, 477

Helal, A.H., 378

Henri, J., 242

Hepworth, J.B., 408

Herman, N., 082, 353
Hermon, P., 009

Herring, J.E., 023

Herubel, J-P.V.M., 218

Hill, D.W., 429

Hill, L., 361

Hoffman, E., 378

Hohn, T., 354

Holm, L.A., 109

Holmberg, B., 202

Holste-Flinspach, K., 190

Horton, F.W., 299

Horton, W.J., 133

Huber, J.T., 166

Hughes, A., 409

Hunt, C.J., 281

Huston, M.M., 255, 259

Hutteman, L., 355

Hutton, S., 253

Hyman, M., 410

Hyman, R., 155

IATLIS see Indian Association of Teachers of Library Science

ICLIS see Intermountain Community Learning and Information Services

IFLA, 444

IFLA, 57th General Conference, Moscow, (1991), 031, 047, 049, 097, 135, 143, 282, 361, 449, 450

IFLA. Continuing Professional Education Round Table, 449

IFLA. Education and Training Section, 450

IFLA. Section on Library Education and Training, 030, 036

ILLINET, 435

Immroth, B.F., 228

Indian Association of Teachers of Library Science. National Seminar, Bangalore, (1991), 105

Information Experts Meeting, Harare, (1991), 355

Information UK 2000, 141

Intermountain Community Learning and Information Services, 199

International Federation for Documentation, 446, 447

International Federation for Documentation. Special Interest Group on Roles, Careers and Development of the Modern Information Professional, 447

International School of Information Management, Santa Barbara, 299

Intner, S.S., 379 
Irving, A., 141, 142, 210

Isenstein, L.J., 411

Jacobson, T.E., 422

Jani, N., 330

Jansch, W., 093, 094

Jehl, M-J., 223

Jilin University of Technology. Department of Information Engineering, 053, 178

Jipeng, J., 178

Johnson, I.M., 143, 191, 256

Johnston, J.L., 233

Jolivet, L., 290

Jones, W.G., 219

Josey, E.J., 289

Kamaldeen, S.M., 138

Karatygina, T.F., 282

Karp, R. Schlessinger see Schlessinger Karp, R.

Katzer, J., 156, 198

Kemper, B., 263

Kenchington, C., 048

Kent State University. School of Library and Information Science, 247

Keriguy, J., 083

Kerzinger, U., 465

Kessler, B., 458

Kharitonov, R.P., 412

Khomenko, G.S., 127

Killenberg, H., 305

Kirkham, S., 179

Klockow, J., 117

Knowles, E.C., 290

Koenig, M.E.D., 331

Kollasch, M., 157

Konn, T., 337

Kossuth Lajos University, Debrecen, 295

Kresakova, J., 306

Kriessman, B., 251

Kruger, J.A., 134

Kummel, G. Bischoff- see Bischoff-Kummel, G.

Kuznetsov, D.N., 128

Laaksovirta, T.H., 061, 062

Lafon, B., 380

Lamblin, P-J., 084

Lancaster, F.W., 024

Langeland, A., 307

Larbre, F., 380

Large, A., 173
Laribee, J.F., 459

Laribee, S.F., 459

Latham, J.M., 413

Lautrap, C.B. Hagen- see Hagen-Lautrap, C.B.

Layzell-Ward, P., 049

Le Bitouze, C., 230

Lee, P., 053

Leonard, B.G., 264

Lerin, V., 460

Leslie, M., 433

Lessing, C.J.H., 451

Lewins, H., 356-358

Lewis, D., 254

Lewis, D.W., 352

LIBEX, 336

Library Association, 376, 440

Library and Information Science Distance Education Consortium, 196

Library and Information Services Council (England), 145

Library of Congress Training the Trainers Course, 379

LISC (England) see Library and Information Services Council (England)

LISDEC see Library and Information Science Distance Education Consortium

Lively, M.L. Rice- see Rice-Lively, M.L.

Loughborough University. Department of Library and Information Studies, 285

Low, K., 414

Lozano, G., 137

Lyders, J.A., 265

MacDougall, J. 356-358

Machnik, M., 359

Makinen, R., 360

Manchester Polytechnic. Department of Library and Information Studies, 192

Manders, I., 308

Mahlmann, P., 291

Manly, W., 158

Manecke, H-J., 309

Marcum, D., 415

Marks, K., 416

Martin, W.J., 310

Martynova, L.S., 361

Mauch, B., 095

Marzano, G., 110

McArthur, M., 324

McAulay, K.E., 266, 417 
McCabe, G., 251

McClure, C.R., 009

McGrath, R., 258

McKeown, T., 478

McKnight, S., 025

McLeod, P., 418

McMahon, P., 377

McRae, L., 461

Meadows, J., 010, 026

Mediadix, 297

MEILLEUR, 336

Meiseles, L., 243

Menou, M.J., 027, 224

Metz, R.E., 419

Metzger, A.J.B., 248

Mezhinene, A.A., 420

Mika, J.J., 203

MINITEL, 208

Miura, I., 112

Moi University. National Library and Information

Science School, 113

Moran, B.B., 283

Moris, J., 085

Morris, A., 253

Morris, B., 479

Morton, M.L., 421

Mularski, C.A., 284

Muller-Benedict, M., 240

Muzykhina, E.P., 128

Nankivell, C., 332, 333

Nasri, W., 211

Nassimbeni, M., 135, 267

National Cohort Study of Newly Qualified Librarians and Information (LIS) Workers, 332, 333

National Online Meeting. New York, (1991), 419, 431

National Vocational Qualifications, 321, 322, 324, 325

Nauta, P., 444

Nawe, J., 362

Nelson, E.M., 406, 414

Nerdrum, L., 124

New Mexico State University Library, 431

Newcastle Polytechnic. Department of Librarian-

ship and Information Studies, 319

Newman, G.C., 363

Niang, T., 224

Nicholson, F., 028, 364
Nicholson, H., 381

Nielsen, S., 416

Niles, N., 422

Nohr, H., 252

North Carolina Central University. School of Library and Information Science, 168

Norwegian School of Library and Information Science, 123, 124, 307, 308

Norwegian School of Library and Information Science. Department of Consultancy and Research, 109, 307

Norwegian School of Library and Information Science. Foundation for Information Technologic Innovation, 308

Nosek, J.T., 029

NVQ see National Vocational Qualifications

Nwali, L.O., 423

Nyeng, P., 055

Odini, C., 424

Okoro, O.M., 122

Ollerman, E., 096

Online Information ' 91,040

Olson, J.E., 287, 471

Ostetag, K., 280

Paez-Urdaneta, I., 180

Parekh, H., 330

Paris, M., 159, 160

Park, A., 425

Parker, S., 480

Parr, E., 452

Parry, J., 382

Pastine, M., 255

Patel, J., 212

Paul, M., 334

Paulides, C., 086

Paz de Erickson, A.M. see Erickson, A.M. Paz de Pennsylvania State University. Libraries, 437

Perrault, A.H., 477

Petrowski, M.J., 426

Phillips, A., 427

Piquemal, M., 087

Plassman, E., 312, 313

Plettenberg, V. Roth- see Roth-Plettenberg, V.

Podmore, E.A., 165

Pontau, D.Z., 264

Poteri, E., 063

Preece, B.G., 428

Pringgoadisurjo, J., 106 
PROGEFIA see General Programme for Training in Agricultural Information

Prokopchik, M.A., 420

Prytherch, R., 384

Puskova, S.V., 365

Quasnichka, J., 325

Queens University Belfast. School of Finance and Information, 310

Raitt, D.E., 040, 393, 433

Raju, A.A.N., 366

Ramberan, K., 438

Randse Afrikaanse Universiteit, 314

Rankka, K., 404

Rao, P.G., 193

Rawan, A., 476

Raymond, B., 052, 129

Reagor, M., 335

Redfern, M., 383

Renoult, D., 076

Rice-Lively, M.L., 268

Richardson, A.D., 120, 204

Riley, G., 336

Rioux, J-P., 088

Roberts, N., 144, 337

Robertson, J., 225

Robson, M., 338

Rochester, M.K., 031, 047

Roper, F.W., 205

Rosenberg, D., 114

Rosic, D. Stancin see Stancin-Rosic, D.

Roth-Plettenberg, V., 117

Roux, P.J.A., 296

Rowland, F., 213

Ruohonen, M., 032

Rusch-Feja, D., 097

Saby, F., 089, 090

Sagna, O., 207

Sangster, A., 214

Satellite On-line Searching Training Interactive

Conferencing Experiment (SOLSTICE), 409

Sayers, M.K., 181

Scanland, R., 476

Schipper, I., 468

Schlessinger, B.S., 033

Schlessinger, J.H., 033

Schlessinger-Karp, R., 033
Schmidt, K.A., 222

Schulz, U., 262

Scottish Vocational Education Council, 322, 324

Scottish Vocational Qualifications, 322, 324

SCOTVEC see Scottish Vocational Educational Council

Secic, D., 164

Seland, G., 124

Sen, B., 330

September, P.E., 339

Sheble, M.A., 429

Shestova, I.G., 216

Short, C., 457

Simmons, W., 315

Simon Bolivar University (Venezuela). Regional Graduate Program in Information Studies, 180 Simonetti, C.M., 249

Sineath, T.W., 146

Skvortsov, V.V., 282

Slater, M., 367, 368, 385

Smet, E. de see De Smet, E.

Smith, A.G., 251

Smith, D., 056, 369

Smith, D.R., 430

Sokolov, A.V., 130

Solimine, G., 111

SOLSTICE see Satellite On-Line Searching Training Interactive Conferencing Experiment Southern Maryland Regional Library Association, 413

Sparks, C.G., 167

Speller, B.F., 168

Stabler, K., 431

Stancin-Rosic, D., 164

STARDOM, 411

Stadtbezirksbibliothek Berlin - Marzahn, 304

Stanyon, M., 481

Starre, J. van der see Van der Starre, J.

Stern, D., 432

Stieg, M.F., 161

STING see Norwegian School of Library and Information Science. Foundation for Information Technologic Innovation

Stokes, S.L., 034

Stubley, P., 433

Sturges, P., 285

Suid-Afrikaanse Biblioteekvereiniging, 451

SVQ see Scottish Vocational Qualifications

Swigger, K., 183, 284

Sykes, P., 434 
Tabet, J., 091

Tallman, J.I., 292-294

Taylor, A.B., 340

Technical Centre for Agricultural and Rural Cooperation, 223

Technische Hochschule Ilmenau/Thuringen, 305, 309

Tees, M., 035-037

Tehnzen, J., 260

Tereshin, V.I., 131

Terroine, M. Wolff- see Wolff-Terroine, M.

Thompson, V., 482

Tiittanen, M. Viljakainen see ViljakainenTiittanen, $M$.

Tikku, U.K., 003

TNA see Training Needs Assessment

Totten, H.L., 171

Toy Libraries Association, 321

Training Needs Assessment (TWA), 382

Trask, M., 039, 386

Trevett, M., 370, 396

Tseng, G.M., 213, 356-358

Turck, B., 269

Turner, C., 466

Turner, J., 234

Umlauf, K., 316

Umney, D., 433

UNESCO, 024, 173

Universite Cheikh Anto Diop de Dakar. Ecole des Bibliothecaires, Archivistes et Documentalistes, 207

Universite de Montreal. Ecole de Bibliotheconomie et des Sciences de l'Information, 207

Universite de Paris X Nanterre. Centre de formation aux carrieres des bibliotheques, du livre et de la documentation, 297

Universite Mohamed V. Rabat. Ecole des Sciences de l'Information, 207

University College of Wales Aberystwyth. Department of Information and Library Studies, 336, 395, 408

University of Alabama. Libraries, 429

University of Arizona. College of Law. Library, 288

University of Arizona. Library, 476

University of Botswana. Department of Library and Information Studies, 186, 315

University of Cape Town. School of Librarianship, 317
University of Georgia Internship Program, 397

University of Ghana. Department of Library and Archival Studies, 100-102

University of Ibadan. Department of Library, Archival and Information Studies, 046, 121, 186

University of Loughborough. Department of Library and Information Studies, 210

University of Madras. Institute of Correspondence Education, 193

University of Missouri-Columbia Intern-Scholar Program, 388

University of Natal Community Resource Centre Training Project, 347

University of Nigeria, Nsukka. Department of Library Studies, 121

University of North Florida, Jacksonville, 245

University of Oregon Applied Information Management Program, 349

University of Pittsburgh. School of Library and Information Science, 166, 287, 289, 471

University of Sheffield. Department of Information Studies, 181

University of South Africa. Department of Library and Information Science, 296

University of South Carolina. College of Library and Information Science, 205

University of Tampere. Centre for Extension Studies, 360

University of Technology, Sydney, 258

University of Texas at Austin. Graduate School of Library and Information Science, 268

University of the South Pacific, 136

University of the West Indies. Department of Library Studies, 301

University of Western Ontario. School of Library and Information Science, 348

University of Zambia. Department of Library Studies, 248

Urdaneta, S. Paez- see Paez-Urdaneta, S.

Van Brakel, P.A., 040, 257

Van der Starre, J.H.E., 119, 174

Victoria College. Department of Information and Numerical Sciences, 177

Victoria University. Department of Library and Information Studies, 120

V.I. Lenin State Library, 361

Viljakainen-Tiittanen, M., 061, 064

Vilnius University, 420

Vingtdeux, N., 092 
Virgo, P., 041

Vodosek, P., 057, 058, 318

Vogeler, H., 319

Vogliano, D., 226

Vorojsky, F.S., 216

Wainwright, E.J., 341

Wallace, F.L., 245

Wallace, S.R., 245

Ward, P. Layzell- see Layzell-Ward, P.

Ware, R., 387

Watson, E., 371

Wayne State University. Library, 394

Wayne State University Library Science Program, 203

Weaver, M., 192

Webb, S.P., 042, 342

Wecker, C.D., 394

Wedgeworth, R., 043

Weech, T.L., 328

Weingand, D.E., 343, 372-374

Weiss, T.W., 378

Wendt, H., 320

Werner, R., 099

Whisler, K., 435

Whitbeck, G.W., 184, 185

White, F.C.P., 200
White, H.S., 162, 246

Wildgoose, D.M., 143

Williams, H.E., 136

Williams, J., 192

Williams, L.B., 250

Wilson, L.A., 426

Wilson, P.J., 265

Wilson, R.A., 214

Wirth, B. Delcker- see Delcker-Wirth B.

Witthus, R.W., 436

Wolff-Terroine, M., 462

Wolfram, D., 006

Women Returners Network, 464

Wood, F.E., 181

Wood, K., 059, 060

Woodward, H., 244

Woolls, B., 375

Wormell, I., 044

Wright, C., 437

Xuereb, P., 115

Yaverbaum, G., 029

Yerbury, H., 258

Zhonglian, Z., 178

Zipkowitz, F., 278 


\section{SUBJECT INDEX}

Academic librarianship, 112, 217-219, 264, 268, 327, 328, 335, 337 339, 352, 356, 357, 360, 363, $370,382,388,396,397,399,415,420,429,431$, 432, 436, 437, 476, 477

Accreditation, 169-171, 452

Acquisitions, teaching, 220-222

Affiliates see Library associations, affiliates

Africa, 045,046, 186, 270, 355, 442

see also names of individual countries

Agricultural librarianship, 223, 224

AIDS awareness, 166

Amalgamations, see Management of change

Appraisal, 327, 329

Archives (profession), 456

Archivists, education, 234, 351, 362, 457

Artificial intelligence, teaching, 245

Art librarianship, 225, 458, 461

Asian Pacific region 047

Associateship, 323

Audiovisual archivists, 234

Audiovisual materials see Media librarianship Australia, 019, 022, 025, 028, 039, 048, 049, 175, $177,189,191,242,258,326,334,338,341,345$, $364,400,452,478$

Bangladesh, 050

Belgium, 051, 176

Bibliographic instruction, teaching, 246, 436 see also User education, teaching

Bibliographic instruction, training, 426, 436

Bibliographies, 001, 002, 123, 134, 212, 254

Bibliography, teaching, 247-250

Bibliotherapy, teaching, 251

Botswana, 186, 315

Brazil, 198

Business archives (profession), 456

CAI see Computer-Assisted Instruction

CAL see Computer-Assisted Learning

Canada, 006, 052, 170, 171, 175, 188, 191, 207,

$211,225,234,252,348,351,474$

Career development, 282, 326-343, 366 see also Career planning

see also Continuing education

see also Professional development

Career planning, 334, 339

see also Career development

see also Continuing education

see also Professional development

Catalogue use, training, 404

Cataloguing, teaching, 235, 236, 238, 239

Cataloguing, training, 429

CD-ROM Interactive, use in training, 393

CD-ROM-XA see CD-ROM Interactive

CD-ROMS, training for use, 419, 431

CD-ROMS, use in training, 393, 437

Change, management of see Management of change

Chartering see Associateship

Children's librarianship, 226-228

China, People's Republic of, 053, 178, 198

Circulation, training, 406

Clerical staff see Non-professional staff

Closures, library schools, 155, 156, 159-162, 300

Communication skills, training, 403

Community information, teaching, 045, 347

Compact Disc - Read Only Memory see CD-ROM

Computer-Assisted Instruction, 261

see also Computers, use in teaching

Computer-Assisted Learning, 207

see also Computers, use in teaching

Computer literacy, training, 413, 421, 423, 432

Computers, use in teaching, 210, 213, 215, 262, 301, 406, 414, 420

see also Computer-Assisted Instruction

see also Computer-Assisted Learning

Conferences, 367, 368

Conservation librarianship, 229, 230, 302, 454

Conservation (profession), 454

Consultancy, 109, 145, 281, 307, 377

Content analysis, teaching, 252

Continuing education, 282, 343-375, 389, 422, 443-447, 449, 450, 453

see also Career development 
see also Professional development

Cooperation in education, 109

Cooperative training, 380

Course design, see Curriculum development

Courses, training see Training courses

Courses of study see types of courses e.g. Professional staff, first qualification courses

Critical thinking, training, 422

Curriculum design, cultural bias, 049

Curriculum development, 002, 049, 172-174, 246

Czechoslovakia, 191, 306

Database construction, teaching, 174

Database use, training, 432

Denmark, 054, 055, 175

Developing countries, 045, 046, 223, 224, 355, 445

Diploma courses, professional staff, 176, 178

see also Professional staff, first qualification courses

Directories, 439

Distance learning, 172, 193-205, 208, 299, 345

see also Open learning

Doctoral research, 003, 016, 182-185

Education, sociology of, 206

Elderly employees, 116

Employment market see Job market

Equal opportunities, 475, 476, 480, 482

see also Ethnic minorities

see also Gender differences

Equivalence (qualifications), 056-060, 097

Ethiopia, 198

Ethnic minorities, 168, 482

see also Equal opportunities

Europe, 056-060, 274-277, 336, 438

see also names of individual countries

Evaluation, library school lecturers, 283

Exchanges see Job exchanges

Expert systems, teaching, 253

Faculty see Lecturers, library school

Fieldwork see Practical work experience

Fiji, 136

Finland, 032, 061-064, 175, 360

France, 065-092, 175, 197, 208, 230, 297, 311, 353, $380,454,456,460,462$

Gender differences, 464, 471, 477, 480

see also Equal opportunities

Germany, 093-099, 175, 190, 237, 240, 260, 262,
263, 269, 291,298, 303-305, 309, 311-313, 316, $318-320,354,359,453,465$

Ghana, 100-103, 344

Harmonization of training, 035, 056-060, 097 see also Equivalence (qualifications)

Health sciences librarianship see Medical and health sciences librarianship

History, 063, 096, 298, 315

Holland see Netherlands

Hungary, 191, 295

Hypertext, use in training, 401, 406

Iceland, 104

In-service training see Training

India, 105, 175, 193, 366

Indonesia, 106

Industrial relations, 478

Information brokerage (profession), 462, 463

Information consultancy see Information brokerage

Information design, teaching, 254

Information management see Information resources management

Information resources management, 018, 022, 023 , $029,032,034,040,041,044,054,120,299,310$, $349,387,455,459$

Information retrieval, teaching, 255-257

Information retrieval, training, 390, 395, 408, 409, 421,435

Information science, education, 012, 020, 021, 026, 027, 029, 032-034, 041, 046, 053, 120, 139 . 208, 310

Information technology, 041, 214, 257, 308 see also headings under Computer see also headings under Networking see also Library automation

Information work, training, 347, 421 see also Reference work

Instructional design see Curriculum development Interlibrary loans, training, 389, 427

Inter-library school cooperation, 109, 311, 318, 319

International students, 211, 289, 292-294

Internship, 388, 397, 415, 429, 436

see also Practical work experience

Interpersonal skills, training, 403, 424

IRM see Information resources management

IT see Information technology

Italy $107-111,235,249$ 
Japan, 112

Job exchanges, 336, 338

Job market, 017, 052, 331-333, 463-482

Job satisfaction, 341

Kenya, 113, 114, 198

Knowledge based learning, 214

LAN see Local Area Networks

Law librarianship, 231-233

Leavers, librarianship, 287

Lecturers, library school, 270-284, 290, 326

Library assistants see Non-professional staff

Library associations and other professional bodies, $007,030,036,146,232,274-277,368,375,376$, $389,438-453,463$

Library associations, affiliate members, 440

Library automation, teaching, 216

Library automation, training, 149, 391, 398, 407, $421,423,425,428,434$

Library school lecturers see Lecturers, library school

Library school/practitioner cooperation, 029,112 , $169,268,290$

Library schools, 016, 048, 098, 100, 101, 109, 113, $121,123,124,128,132,133,147,150,155,156$, $166-168,183,215,225,229,248,253,270,283$, 295-320, 335, 372

Library science collections, 007

Library technicians see Para-professional staff

Literature searching see Reference work

Lithuania, 420

Local Area Networks, training, 416, 419

see also Networking, electronic

Malaysia, 198

Malta, 115

Management, education, 022, 025, 032, 143, 348

Management of change, teaching, 025, 360, 400

Management of change, training, 407

Management, training, 376, 378, 386, 388, 415

Manpower development see Training

Manpower planning, 042, 130, 141, 466, 469

Marketing, teaching, 258

Masters courses, professional staff, 046, 175, 179, $180,181,193$

see also Professional staff, first qualification courses

Media librarianship, 210, 234, 418, 460

Medical and health sciences librarianship, 408
Mentoring, 268

Mergers see Management of change

Methods of teaching see Teaching methods

Mexico, 198

Morocco, 198, 207

Multi-skilling, 028

Multimedia packages, use in training 433

Music librarianship 235-240

National Information Plans, 010

National Vocational Qualifications, 321, 322, 324, 325

Netherlands, 116-119, 174, 175, 241, 468

Networking, electronic, 198, 199, 207

see also Local Area Networks

New Zealand, 004, 120, 204, 327, 386, 470

Nigeria, 046, 121, 122, 186, 198, 423

NIPS see National Information Plans

Nordic countries, 015

see also names of individual countries

Northern Ireland, 310

Norway, 109, 123, 124, 175, 307, 308

NVQ see National Vocational Qualification

Online catalogues, training, 404, 428, 435

Online information retrieval, teaching see Information retrieval, teaching

OPACS see Online catalogues

Open learning, 192-205, 208, 345

see also Distance learning

Overseas placements, 269

see also Practical work experience

Pakistan, 125

Papua New Guinea, 346, 350

Paraprofessional staff, education, 186-191, 369, 372, 374

Paraprofessional staff, training, 399, 430, 434

Part-time study see Open learning

PDR see Professional Development Report

Placements see Practical work experience

Planning, 167

Poland, 126

Portugal, 302

Practical work experience, 263-269, 272, 288

Practicum see Practical work experience

Preservation librarianship, 229, 230, 402

Preservation, training, 402

Professional bodies, see Library associations 
Professional development, 195, 327, 337, 340-342, Statistics, 146

366, 370

see also Career development

see also Continuing education

Professional Development Report, 323

Professional qualifications, 067, 082, 084, 321325, 458

see also Associateship

Professional staff, first qualification courses, 124, 175-181

Psychological testing, 209

Public librarianship, 096, 116, 227, 241, 338, 358, 380, 403, 411, 413

Public services, training for, 403-405

Qualifications, see Professional qualifications

Recruitment, 042, 114, 116, 122, 271, 285, 289, 290, 473, 475

Reference work, teaching, 226, 259, 260

see also Information work

Reference work, training, 264, 392, 405, 411, 412, $421,430,433,435$

see also Information work

Research, 003-010, 016, 123, 134, 164, 253, 279, 284

Research methods, teaching, 261, 285

Returners, 464, 479

Rural librarianship, 045, 195, 203, 345

Russia, 127-131, 209, 216, 282, 361, 412

Sahel, 442

Satellites, use in training, 409

Scandinavia see names of individual countries

School librarianship, 242

Scotland, 143, 322, 324

Scottish Vocational Qualifications, 322, 324

Seminars see Conferences

Senegal, 207

Serials librarianship, 243, 244

Software support, 410

South Africa, Republic of, 018, 132-135, 267, 286, 296, 314, 317, 347, 451

South America, 180

see also names of individual countries

South Pacific region, 136

Spain, 012, 137

Special librarianship, 096, 140, 342

Sri Lanka, 138

Staff development see Training
Students, 211, 267, 285-294, 429

Students, evaluation of, 212

Subject indexing, teaching, 262

Subject specialisation, 218, 219, 231, 250, 328

SVQ see Scottish Vocational Qualifications

Switzerland, 238

Systems analysis, teaching, 216

\section{Tanzania, 362}

Teacher librarians, see School librarianship

Teaching methods, 206-216, 348

Teaching staff, see Lecturers, library school

Technical services, training, 391

Technicians, library see Paraprofessional staff

TNA see Training Needs Assessment

Training general, 048, 141, 334, 339, 352, 356, 357, $363,366,376-387,438,443,446$

Training, specialised, $233,388-437$

Training courses, 367,368

see also Continuing education

see also Professional development

Training Needs Assessment, 382

Training to train, 379,426

Transferable skills, 331, 455

Tunisia, 139, 140

\section{UK see United Kingdom}

Undergraduate courses, professional staff, 177, 192

see also Professional staff, first qualification courses

United Kingdom, 008, 010, 013, 023, 038, 041, 042, $141-145,175,179,181,191,192,200,210$, 212-215, 217, 254, 256, 266, 281, 285, 310, 319, $321-325,329,332,333,336,337,340,342$, 356-358, 367, 368, 375, 381, 382, 384, 385, 393, $395,399,408,409,417,433,434,438,440,455$, 457, 464, 466, 472, 473, 475, 479-482

United States of America, 003, 005, 007, 014, 016, 021, 029, 033, 043, 146-162, 166, 168-171, 175, $182-185,187,191,194-196,199,201,203,205$, 211, 212, 218-222, 225-229, 231-233, 236, 243, $245-247,250-252,255,259,264,265,268$, 271-273, 278-280, 283, 284, 287-290, 292-294, $299,300,328,335,338,339,348,349,352,363$, $365,369,370,372-374,377,379,388,389,391$, $392,394,396-398,403-407,411,413,415,416$, $418,419,422,425-427,429-432,435-437,439$, 
$441,443,448,458,459,461,463,467,469,471$, Wales, 336, 395, 408

476,477

USA see United States of America

User education, teaching, 250

see also Bibliographic instruction, teaching

User education, training, 417

Vendors, role in education and training, 410

Venezuela, 180

Visual resource curators, 458,461

Visual resources collections, 225

West Africa, 442

see also names of individual countries

West Indies, 301, 371

Women employees, 464, 471, 479-481

Workshops see Training courses

Youth librarianship, see Children's librarianship Yugoslavia, 163, 164

Zambia, 248

Zimbabwe 165 


\section{LIST OF PERIODICAL TITLE ABBREVIATIONS}

Ann.Jap.Soc.Lib.Sci.: Annals of Japan Society of Library Science Aust.Pub.Lib: Australasian Public Libraries and Information Services Bib.i.Bib.Rub.: Bibliotekovedenie i Bibliografiya za Rubezhom Brit.J.Acad.Lib.: British Journal of Academic Librarianship Buch u.Bib.: Buch und Bibliothek Bull.ASIS: Bulletin of the American Society for Information Science Bull.Bib.France: Bulletin des Bibliotheques de France Bull.Inf.ABF.: Bulletin d'Information ABF

Cad.Bib.Arq.Doc.: Cadernos de Biblioteconomia, Arquivistica e Documentacao

Can.J.Inf.Sci.: Canadian Journal of Information Science Coll.\& Res.Lib.News: College and Research Libraries News

CTI Cent.Lib.\& Inf.Studies News: Computers in Teaching Initiative Centre for Library and Information Studies Newsletter

Educ.Lib.Aust.: Education for Librarianship: Australia

Eur.Res.Lib.Coop.: European Research Libraries in Cooperation

Expert Sys.Inf.Man.: Expert Systems for Information Management

Foc.Int.\& Comp.Lib.: Focus on International and Comparative Librarianship

Her.Lib.Sci.: Herald of Library Science

Inf.Bull.West.Assoc.Map Lib.: Information Bulletin of the Western Association of Map Librarians

Inf.Proc.\& Man.: Information Processing and Management

Inf.Res.Man.J.: Information Resource Management Journal

Inf.Tech.Publ.Pol.: Information Technology and Public Policy

Int.J.Inf.Man.: International Journal of Information Management

Int.Lib.Rev.: International Library Review

J.Acad.Lib.: Journal of Academic Librarianship

J.Educ.Lib.\& Inf.Sci.: Journal of Education for Library and Information Science

J.Inf.Sci.: Journal of Information Science

J.Inf.Sys.: Journal of Information Systems

J.Inf.Sys.Man.: Journal of Information Systems Management

J.Lib.Admin.: Journal of Library Administration

J.Soc.Arch.: Journal of the Society of Archivists

Kir.ja.Inf.: Kirjastotiede ja Informatikka

Leg.Ref.Serv.Q.: Legal Reference Services Quarterly

Lib.Admin.\& Man.: Library Administration and Management

Lib.\& Inf.Asst.: Library and Information Assistant

Lib.\& Inf.Sci.Res.: Library and Information Science Research

Lib.Ass.Rec.: Library Association Record

Lib.Res.\& Tech.Serv.: Library Resources and Technical Services

Mitt.Verb.Bib.Land.Nord.: Mitteilungsblatt Verband der Bibliotheken des Landes Nordrhein-Westfalen

Nach.Dok.: Nachrichten fur Dokumentation

Nauch.Tek.Bib.SSSR.: Nauchnye i Tekhnisheskie Biblioteki SSSR

Out.Res.Lib.: Outlook on Research Libraries 
Per.Train.\& Educ.: Personnel Training and Education

Q.Bull.IAALD: Quarterly Bulletin of the International Association of Agricultural Information Specialists

Rev.Esp.Doc.Cient.: Revista Espanola de Documentacion Cientifica

S.Afr.J.Lib.\& Inf.Sci.: South African Journal of Library and Information Science

Scand.Pub.Lib.Q.: Scandinavian Public Library Quarterly

Tud.Mus.Taj.: Tudomanyos es Muszaki Tajekoztatas

Zambia Lib.Ass.J.: Zambia Library Association Journal 